\title{
Electronic Control of Spin-Crossover Properties in Four-Coordinate Bis(formazanate) Iron(II) Complexes
}

\author{
Francesca Milocco, Folkert de Vries, Imke M. A. Bartels, Remco W. A. Havenith, Jordi Cirera, \\ Serhiy Demeshko, Franc Meyer, and Edwin Otten*
}

Cite This: J. Am. Chem. Soc. 2020, 142, 20170-20181

Read Online

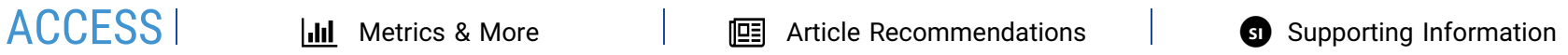

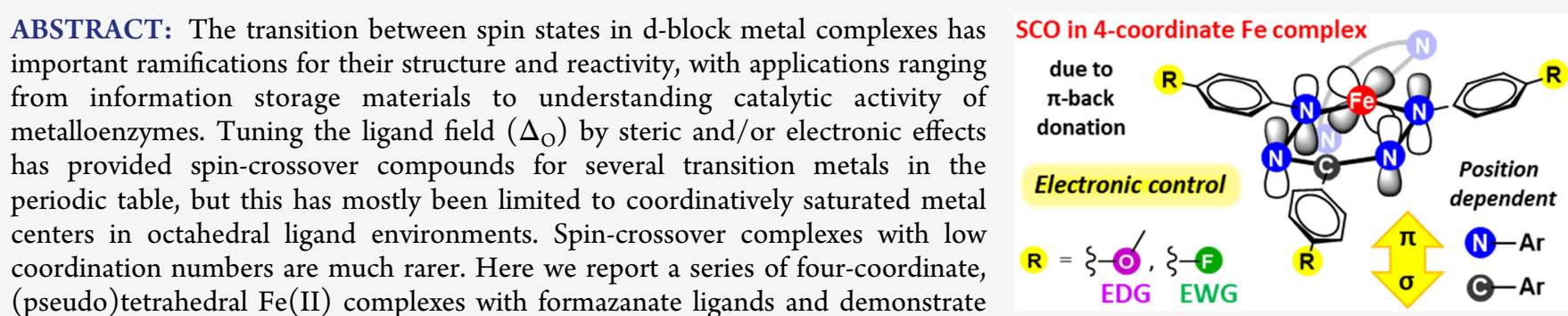
how electronic substituent effects can be used to modulate the thermally induced transition between $S=0$ and $S=2$ spin states in solution. All six compounds undergo spin-crossover in solution with $T_{1 / 2}$ above room temperature $(300-368 \mathrm{~K})$. While structural analysis by X-ray crystallography shows that the majority of these compounds are low-spin in the solid state (and remain unchanged upon heating), we find that packing effects can override this preference and give rise to either rigorously high-spin (6) or gradual spin-crossover behavior (5) also in the solid state. Density functional theory calculations are used to delineate the empirical trends in solution spin-crossover thermodynamics. In all cases, the stabilization of the low-spin state is due to the $\pi$-acceptor properties of the formazanate ligand, resulting in an "inverted" ligand field, with an approximate "two-over-three" splitting of the d-orbitals and a high degree of metal-ligand covalency due to metal $\rightarrow$ ligand $\pi$ backdonation. The computational data indicate that the electronic nature of the para-substituent has a different influence depending on whether it is present at the $\mathrm{C}-\mathrm{Ar}$ or $\mathrm{N}-\mathrm{Ar}$ rings, which is ascribed to the opposing effect on metal-ligand $\sigma$ - and $\pi$-bonding.

\section{INTRODUCTION}

Molecular materials that can be switched between two (or more) spin states are of interest for their potential application in electronic devices such as sensors and data storage. In addition to materials applications, compounds in different spin state have vastly different reactivity, and this has implications in catalytic reactions both in biology and in synthetic chemistry. ${ }^{1}$ Although initial observations of spin-crossover behavior were described by Cambi and co-workers as early as $1931,{ }^{2}$ it took more than 50 years before a more general understanding of the phenomenon was developed and its relevance more widely appreciated. ${ }^{3}$ Despite the advances in the past decades, it is still not straightforward to rationally design spin-crossover compounds. This is a reflection of the small energy difference that is associated with a change in spin state. The vast majority of compounds that show spin-crossover behavior is based on six-coordinate transition metal complexes. ${ }^{4}$ The energies within the d-orbital manifold (e.g., the ligand-field splitting energy, $\Delta_{\mathrm{O}}$, in an octahedral complex) can be manipulated by exploiting ligand effects, which allows tuning of the relative stability of the various spin states. ${ }^{5}$ Complexes based on a $\mathrm{d}^{6}$ $\mathrm{Fe}(\mathrm{II})$ ion coordinated by six nitrogen-based ligands $\left(\mathrm{FeN}_{6}\right)$ are arguably the most well-studied examples of spin-crossover compounds due to the large change in magnetism that results from transitions between the low-spin, diamagnetic $(S=0)$ state to a high-spin $(S=2)$ state. $^{6}$ Changes in the steric and/or electronic properties of the ligands bound to the metal center are known to alter the spin-crossover behavior, which can most concisely be described by the so-called spin-crossover temperature $\left(T_{1 / 2}\right)$, that is, the temperature at which both spin states are equally populated. At this temperature, the difference in enthalpy $(\Delta H)$ between the low- and high-spin states is equal to the difference in the entropic contribution to the Gibbs free energy $(T \Delta S)$.

In addition to the influence exerted on spin-crossover properties by ligands that are directly attached to the metal center, the importance of packing effects (in the solid state), the influence of the (noncoordinating) counterions, and intermolecular interactions (e.g., hydrogen bonding) can be

Received: September 22, 2020

Published: November 16, 2020 


\section{Chart 1}
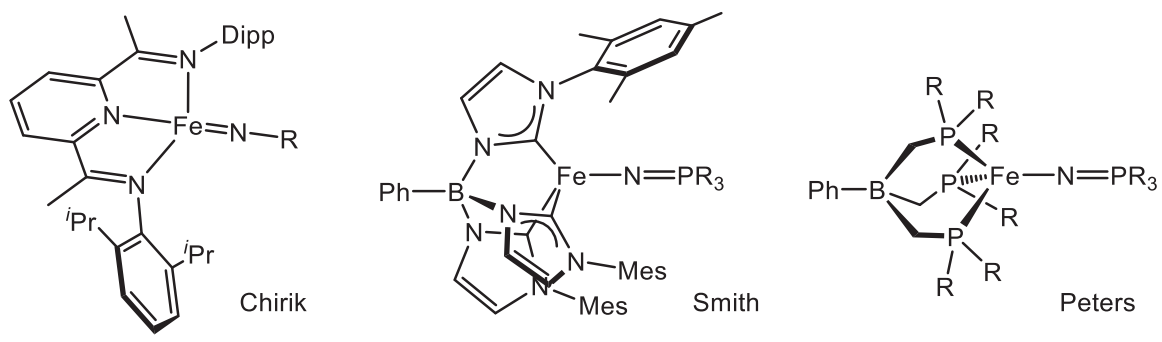

$\mathrm{S}=0 \rightleftharpoons \mathrm{S}=1$

$S=0 \rightleftharpoons S=2$

$\mathrm{S}=0 \rightleftharpoons \mathrm{S}=2$

\section{Scheme 1. Synthesis of Compounds 1-6}
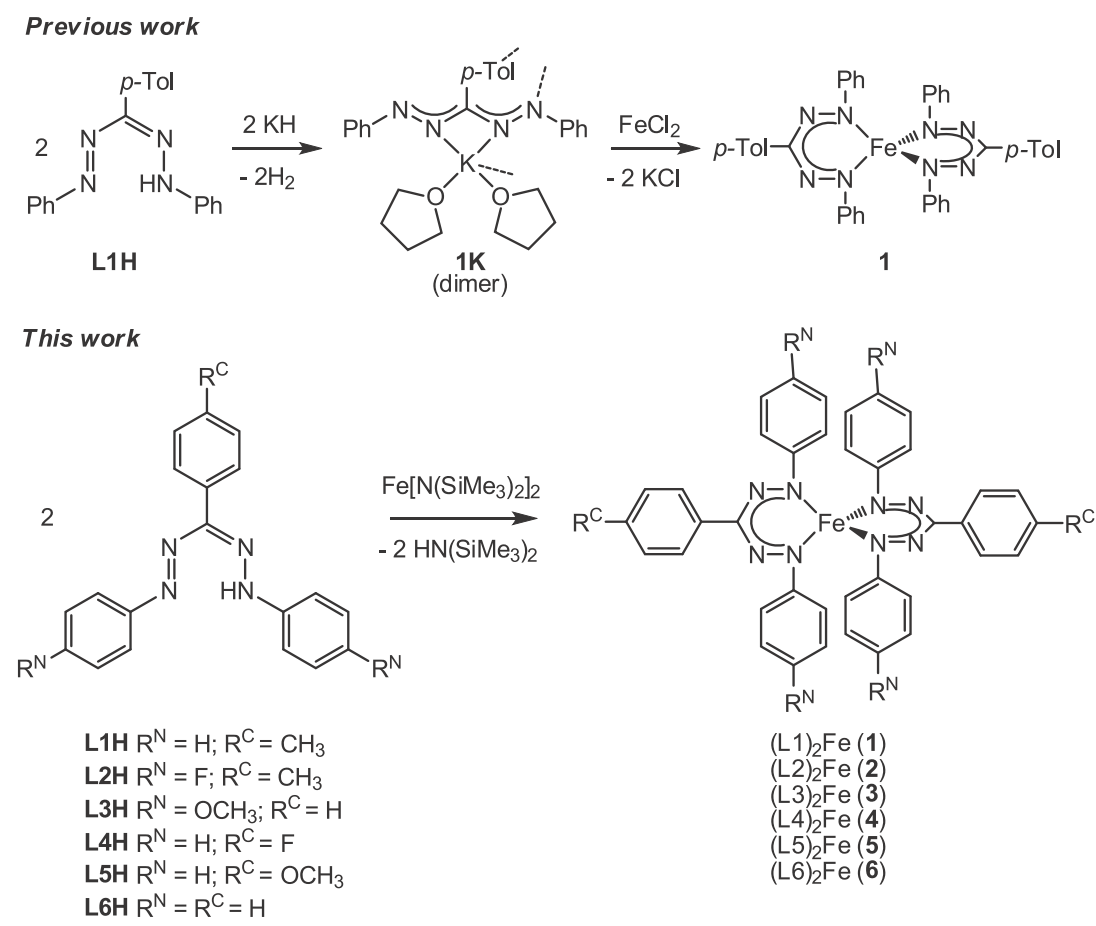

of similar magnitude as (or even more important than) intrinsic molecular properties, and these effects can lead to interesting cooperative behavior. ${ }^{4,7,8}$

In contrast to the established class of octahedral compounds, four-coordinate $3 \mathrm{~d}$ transition metal complexes have much smaller splitting energies and are therefore in general high-spin. For $\mathrm{Fe}(\mathrm{II})$ compounds, a few notable exceptions are known: Chirik's square-planar (PDI)Fe imido complexes (PDI = pyrridinediimine), ${ }^{9}$ and complexes with tris(carbene)- or tris(phosphine)borate ligands in the presence of phosphoraniminato coligands by Smith ${ }^{10}$ and Peters, ${ }^{11}$ respectively, have been reported to show spin-crossover (Chart 1). The latter compounds are unique in the sense that the geometrical constraints in the ligand enforce a trigonal symmetry ("umbrella" distortion) that leads to a d-orbital energy splitting diagram resembling that of an octahedron. ${ }^{12,13}$ In combination with a strong $\pi$-donor as the fourth ligand this has been shown to result in spin-crossover behavior that may be tuned via steric and electronic substituent effects. ${ }^{10 b}$ In 2016, we reported a four-coordinate $\mathrm{Fe}$ (II) spin-crossover complex with formazanate ligands. ${ }^{14}$ The unusual stability of the low-spin state in this compound was shown to originate from an "inverted" ligand field that is due to the $\pi$-acceptor properties of the ligand which stabilizes one of the d-orbitals that is antibonding in a "classical" tetrahedral complex and gives rise to a "twoover-three" splitting pattern reminiscent of an octahedral ligand field. Metal complexes in low-coordinate environments are important from the perspective of reactivity/catalysis, and thus an understanding of the ways in which the spin state of such compounds can be modulated is highly desirable. In this contribution we evaluate the influence of electronic substituent effects on spin-crossover properties in triarylformazanate iron(II) complexes. Combining solid-state structural analysis from X-ray crystallography, spin-crossover thermodynamics in solution (NMR, UV/vis), and computational studies, we delineate the factors that govern spin-crossover in this class of compounds. The data indicate that para-substituents on the ligand $\mathrm{N}-\mathrm{Ar}$ or $\mathrm{C}-\mathrm{Ar}$ rings have an opposite effect on solution thermodynamics, which can be ascribed to competing influences on metal-ligand $\sigma$ - and $\pi$-bonding.

\section{RESULTS AND DISCUSSION}

Synthesis of Bis(formazanate) Iron(II) Complexes. Treatment of $\mathrm{Fe}\left[\mathrm{N}\left(\mathrm{SiMe}_{3}\right)_{2}\right]_{2}$ with 2 equiv of formazan $\mathbf{L} \mathbf{1 H}$ on the NMR scale in THF- $d_{8}$ resulted in complete conversion of the starting materials and appearance of the signals of the known bis(formazanate) iron complex $1,{ }^{14}$ with concomitant formation of $\mathrm{HN}\left(\mathrm{SiMe}_{3}\right)_{2}$. Performing the reaction on a 


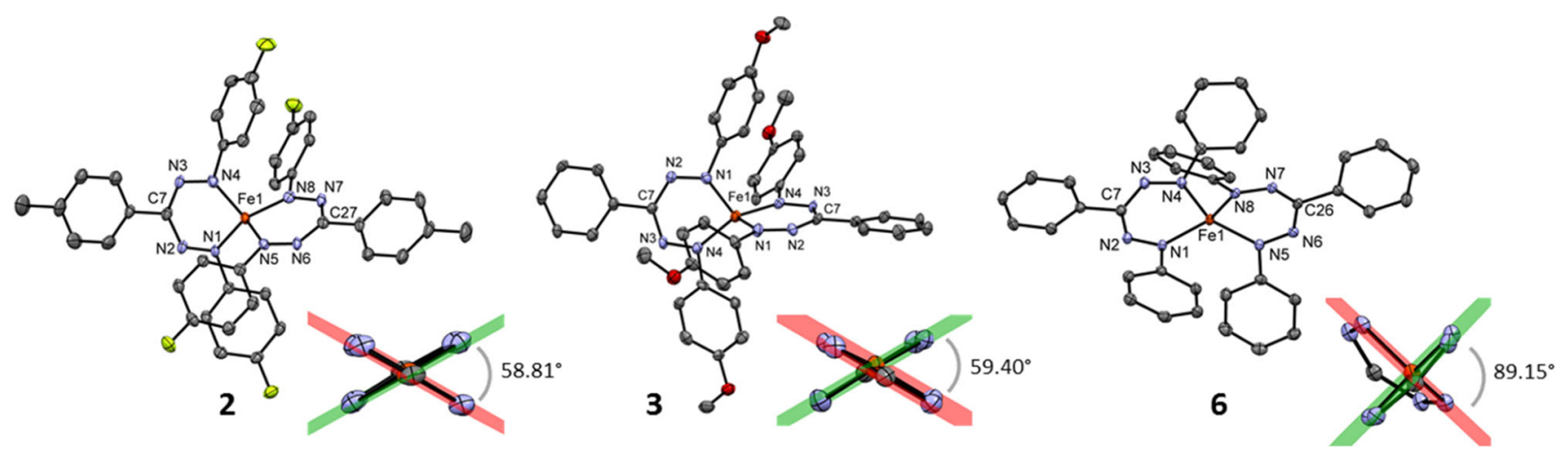

Figure 1. Molecular structure of compounds 2, 3, and 6 showing 50\% probability ellipsoids; hydrogen atoms are omitted for clarity. The inset for each shows the $\mathrm{Fe}(\mathrm{NNCNN})_{2}$ core of the structure with the $\mathrm{N}-\mathrm{Fe}-\mathrm{N}$ planes and their dihedral angle.

preparative scale, followed by crystallization from hot hexane, gave compound 1 in a good isolated yield of $84 \%$. This synthetic protocol was subsequently performed with a variety of formazanate ligands $(\mathbf{L} \mathbf{2} \mathbf{H}-\mathbf{L} 6 \mathbf{H})$ that differ in their substitution patterns, which in all cases led to straightforward, clean formation of the new homoleptic bis(formazanate) iron complexes 2-6 with minimal work-up involved (Scheme 1). Compounds 1-6 all have symmetric triaryl formazanate ligands differing from each other from the substituents in the para-position of the aromatic rings, which allows us to investigate electronic effects on spin-crossover in these compounds without structural perturbations due to changes in steric properties. Specifically, we focus on a comparison between electron-withdrawing $(\mathrm{R}=\mathrm{F})$ and electron-donating $(\mathrm{R}=\mathrm{OMe})$ substituents on the aromatic groups $\left(-\mathrm{C}_{6} \mathrm{H}_{4}-p-\mathrm{R}\right)$ on either the $\mathrm{C}$ or $\mathrm{N}$ atoms of the formazanate backbone $\left(\mathrm{R}^{\mathrm{C}}\right.$ and $\mathrm{R}^{\mathrm{N}}$, see Scheme 1).

X-ray Crystallography. The solid-state structures of compounds 2-6 were established by using X-ray crystallography at $100 \mathrm{~K}$ (the structure of 1 was communicated previously $\left.{ }^{14}\right)$. As anticipated, the structure determination shows a pseudotetrahedral coordination geometry in which the central $\mathrm{Fe}$ ion is coordinated by the terminal nitrogen atoms of two bidentate formazanate ligands. The molecular structures of three selected examples (complexes 2, 3, and 6) are shown in Figure 1; a comparison of pertinent metrical parameters is given in Table S1. Similar to the X-ray structure of 1 measured at $100 \mathrm{~K},{ }^{14}$ all compounds (with the exception of 6 , vide infra) feature short $\mathrm{Fe}-\mathrm{N}$ bond lengths in the range 1.809-1.847 $\AA$ that are indicative of a low-spin state for the complexes 2-5. Structurally related high-spin Fe(II) complexes have been reported to have significantly larger $\mathrm{Fe}-\mathrm{N}$ distances (e.g., $1.98 \AA$ in $\left[(\mathbf{1}) \mathrm{FeX}_{2}\right]\left[\mathrm{NBu}_{4}\right]^{15} 2.02 \AA$ in a bis $(\beta$-diketiminate $)$ iron complex $\left.{ }^{16}\right)$. In addition, the intraligand $\mathrm{N}-\mathrm{N}$ bonds in $\mathbf{1 - 5}$ are slightly elongated (1.32-1.33 $\AA$ ) compared to the typical bond lengths found in complexes with triarylformazanate ligands (1.29-1.31 $\AA$ ). These features can be attributed to $\pi$-backdonation from a filled Fe d-orbital into the empty $\pi^{*}$-orbital of the formazanate ligand. ${ }^{14}$ In agreement with this notion, complexes $\mathbf{1 - 5}$ show a flattening of the tetrahedral geometry, with dihedral angles $\angle(\mathrm{N}-\mathrm{Fe}-$ $\mathrm{N}) /(\mathrm{N}-\mathrm{Fe}-\mathrm{N})$ between the ligand coordination planes of around $60^{\circ}$ for $1-4$ and ca. $70^{\circ}$ for 5. The substantial distortion from $90^{\circ}$ allows maximizing of the $\pi$-backbonding interaction without causing prohibitive steric pressure between adjacent $\mathrm{N}-$ Ar groups.
Even though compound $\mathbf{1}$ was shown to undergo spincrossover in the solid state at $428 \mathrm{~K},{ }^{14}$ differential scanning calorimetry (DSC) for compounds 2-4 does not indicate changes to these compounds up to the decomposition temperature, indicating that in the solid state no spin-crossover occurs.

To our surprise, the molecular structure (determined by Xray crystallography at $100 \mathrm{~K}$ ) of the closely related compound 6, which differs only from 1 by the absence of the $p$-tolyl $\mathrm{R}^{\mathrm{C}}=$ Me groups in the $\mathrm{C}-\mathrm{Ar}$ position, is markedly different (Figure 1). Instead of the "flattened" tetrahedral structure observed for $\mathbf{1 - 5}$, the formazanate ligands in $\mathbf{6}$ are virtually perpendicular to each other, with a dihedral angle between the ligand coordination planes of $89.15(9)^{\circ}$. Moreover, the $\mathrm{Fe}-\mathrm{N}$ distances in the solid-state structure of 6 are long (1.9532(15)-1.9812(15) $)$ ), suggesting that 6 is high-spin. The result that $\mathbf{1}$ and $\mathbf{6}$ are distinctly different in the solid state is unexpected: analysis of close contacts in the solid-state structures does not provide evidence for differences in intermolecular interactions, and it thus appears that subtle effects (e.g., packing in the solid state) can be sufficient to override any electronic preference for either geometry (and, by extension, spin state). The importance of solid-state packing effects is well-established in six-coordinate $\mathrm{Fe}(\mathrm{II})$ spincrossover compounds, where factors such as crystal density (polymorphs), $\pi-\pi$ stacking interactions, or the incorporation of different (noncoordinating) anions can have significant effects on spin-crossover. ${ }^{7 \text { a }}$

For compound 5, the observation of an endothermic peak at $448 \mathrm{~K}$ in the DSC curve (see the Supporting Information) suggested that this compound could show spin-crossover in the solid state. Moreover, the interligand dihedral angle in compound $\mathbf{5}$ of $69.38(7)^{\circ}$ is closer to the high-spin value than that in $\mathbf{1 - 4}$. A variable temperature X-ray crystallography study for $\mathbf{5}$ indeed provided evidence for a (gradual) spin transition in the solid. Analysis of the data between $100 \mathrm{~K}$ and room temperature suggests little change, with consistently short $\mathrm{Fe}-\mathrm{N}$ distances (average 1.830-1.838 $\AA$ ) and dihedral angles between ligand coordination planes of $69.4(1)^{\circ}-$ $70.6(1)^{\circ}$. Upon going to higher temperatures, a steady increase in both metrical parameters is observed, reaching an average $\mathrm{Fe}-\mathrm{N}$ bond length of $1.930 \AA$ at $425 \mathrm{~K}$ and an NFeN/NFeN angle of $77.8(4)^{\circ}$ (Figure 2). Attempts to determine the structure at even higher temperature $(450 \mathrm{~K})$ resulted in reasonable diffraction images (given the high temperature), but indexing of the spots was problematic. From the time evolution 


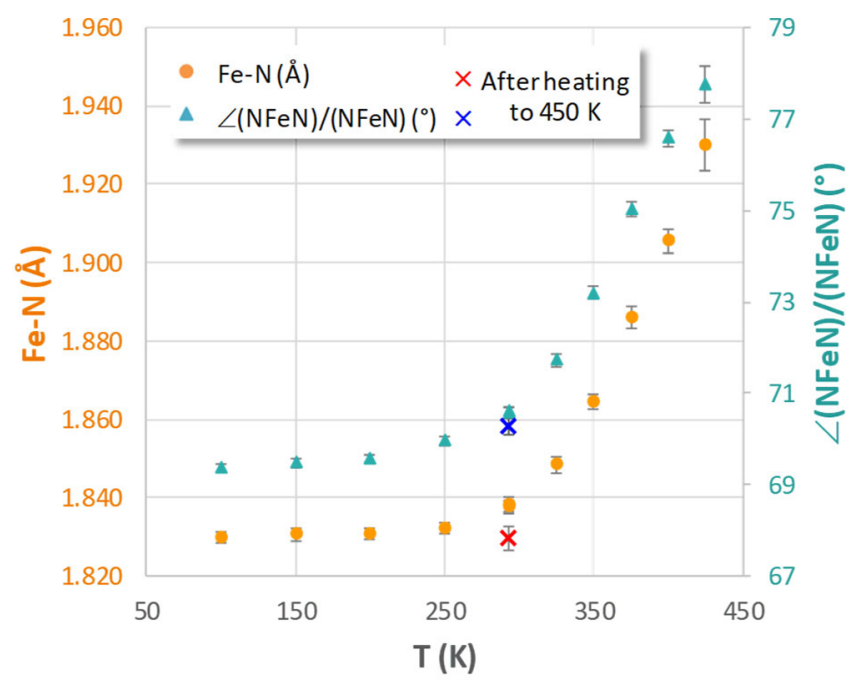

Figure 2. Average $\mathrm{Fe}-\mathrm{N}$ bond lengths (orange circles) and dihedral angle between ligand coordination planes (blue triangles) as a function of temperature in a single crystal of compound 5. The crosses correspond to the structure after heating to $450 \mathrm{~K}$ and loss of the solvent molecule. Error bars show the estimated standard deviations obtained from the X-ray analysis.

of the diffraction images at $450 \mathrm{~K}$ it appeared that the crystal gradually underwent a single-crystal-to-single crystal transformation during data acquisition. Subsequent cooling and data collection at room temperature allowed determination of the newly formed crystal structure. Although the crystal still shows a monoclinic setting (space group $P 2_{1} / n$ ), there are slight changes to the unit cell parameters which result in a volume that is noticeably smaller $\left(3673.0(4)\right.$ and $3564.9(6) \AA^{3}$ before and after heating to $450 \mathrm{~K}$, respectively). The structure determination before heating showed the presence of smearedout electron density (attributed to a disordered THF solvate molecule) and a high degree of rotational disorder in one of the ligand $\mathrm{N}-\mathrm{Ph}$ rings. After heating to $450 \mathrm{~K}$, the solvent molecule is lost, and no disorder is observed anymore. The thermally induced loss of solvent from the crystal lattice has been reported to be associated with differences in magnetic properties for many spin-crossover compounds, ${ }^{17}$ but for compound 5 that does not appear to be the case: both before and after heating the structures measured at $293 \mathrm{~K}$ show virtually identical (short) $\mathrm{Fe}-\mathrm{N}$ distances and "flattened" tetrahedral coordination geometries (see the Supporting Information for details). It should be noted that the gradual changes in the metrical parameters for $\mathbf{5}$ stand in marked contrast to the VT crystallography for 1: in the latter compound, the structure is unchanged between 100 and 400 $\mathrm{K}$, but an abrupt transition is observed to take place at $428 \mathrm{~K}$ which results in a $7 \%$ increase in cell volume in response to the increase in $\mathrm{Fe}-\mathrm{N}$ distances due to spin-crossover. ${ }^{14} \mathrm{~A}$ recent variable-temperature $\mathrm{X}$-ray diffraction study of a six-coordinate $\mathrm{Fe}$ (II) spin-crossover compound showed gradual changes as a function of temperature, which were deconvoluted into purely thermal and spin-transition effects by comparison to the $\mathrm{Zn}$ (II) analogue. ${ }^{18}$ This analysis suggests that during the gradual transition a random distribution of low- and high-spin molecules occurs rather than the formation of discrete domains. ${ }^{19}$ A similar situation is likely the case for $\mathbf{5}$, since no discrete Braggs peaks are observed for low- and high-spin domains. $^{20}$

Mössbauer Spectroscopy and SQUID Magnetometry Studies in the Solid State. Complexes 1-6 were further characterized by Mössbauer spectroscopy, which provides information about the charge density at the Fe nucleus (via the isomer shift, $\delta$ ) and the asymmetry of the charge distribution (via the quadrupole splitting, $\left|\Delta E_{\mathrm{q}}\right|$ ). Compounds 2-5 show low isomer shifts of $0.01-0.05 \mathrm{~mm} / \mathrm{s}$ (Table 1 ), similar to that of 1 reported previously $(0.03 \mathrm{~mm} / \mathrm{s}) .{ }^{14}$ Despite the fact that the molecular structure of $\mathbf{6}$ is distinct from the others, its Mössbauer spectrum (of a powder sample) showed similar parameters as the others $\left(\delta=0.03 \mathrm{~mm} / \mathrm{s} ;\left|\Delta E_{\mathrm{q}}\right|=1.82 \mathrm{~mm} / \mathrm{s}\right)$. Although this is surprising, we demonstrate below that it can be explained by packing effects in the crystalline state.

The Mössbauer parameters for $\mathbf{2} \mathbf{- 6}$ were calculated by using the method reported by Neese and co-workers, ${ }^{21}$ using either the crystallographic coordinates or those that result from geometry optimization (Table 1). On the singlet surface, compounds $2-5$ converge on minima that closely reproduce the X-ray structures with "flattened" tetrahedral structures and short $\mathrm{Fe}-\mathrm{N}$ distances (a more detailed discussion of the DFT geometries/energies is provided below), and the calculated Mössbauer isomer shifts $(\delta=-0.01 \mathrm{~mm} / \mathrm{s})$ are in good agreement with those measured experimentally $(\delta=0.01-0.05$ $\mathrm{mm} / \mathrm{s})$. For compound 6 , on the other hand, the optimized

Table 1. Mössbauer Parameters $\left(\delta=\right.$ Isomer Shift in $\mathrm{mm} \mathrm{s}^{-1} ;\left|\Delta E_{\mathrm{q}}\right|=$ Quadrupole Splitting in $\left.\mathrm{mm} \mathrm{s}^{-1}\right)$ for $1-6^{a}$

\begin{tabular}{|c|c|c|c|c|c|c|}
\hline & 1 & 2 & 3 & $4^{b}$ & 5 & 6 \\
\hline$\delta_{\exp }$ & 0.03 & 0.01 & 0.02 & 0.03 & 0.05 & $\begin{array}{l}0.03 \text { (LS) } \\
0.60(\mathrm{HS})\end{array}$ \\
\hline$\delta_{\text {calc }}{ }^{c}$ & -0.03 & -0.05 & -0.02 & -0.04 & 0.01 & $\begin{array}{l}0.47 \text { (LS) } \\
0.51(\mathrm{HS})\end{array}$ \\
\hline$\delta_{\text {calc }}^{d}$ & -0.01 & -0.01 & -0.01 & -0.01 & -0.01 & $\begin{array}{r}-0.01(\mathrm{LS}) \\
0.55(\mathrm{HS})\end{array}$ \\
\hline$\left|\Delta E_{\mathrm{q}}\right|_{\exp }$ & 2.05 & 2.19 & 2.19 & 1.99 & 1.56 & $\begin{array}{l}1.82(\mathrm{LS}) \\
0.91(\mathrm{HS})\end{array}$ \\
\hline$\Delta E_{\mathrm{q}, \text { calc }}{ }^{c}$ & -1.93 & -1.97 & -2.17 & -1.79 & -1.40 & $\begin{array}{l}2.85(\mathrm{LS}) \\
1.25(\mathrm{HS})\end{array}$ \\
\hline$\Delta E_{\mathrm{q}, \text { calc }}{ }^{d}$ & -1.46 & -1.49 & -1.51 & -1.47 & -1.45 & $\begin{array}{r}-1.47(\mathrm{LS}) \\
1.34(\mathrm{HS})\end{array}$ \\
\hline
\end{tabular}

${ }^{a}$ Measured in the solid state at $80 \mathrm{~K}$ unless noted otherwise. ${ }^{b}$ Measured at $7 \mathrm{~K}$. ${ }^{c}$ Calculated by using the crystallographic coordinates; values for $1-$ 5 are for the LS state, except for $\mathbf{6}$ (LS/HS). ${ }^{d}$ Calculated at the optimized geometry for $\mathbf{1 - 5}$ (LS, OPBE/def2-TZVP). Values for $\mathbf{6}$ are given for both spin states (LS/HS). 
singlet geometry resembles the other low-spin compounds but is distinctly different from the structure determined by X-ray crystallography. The Mössbauer isomer shift calculations are sensitive to these differences in geometry: at the optimized geometry for LS $\mathbf{6}$ the computed isomer shift is the same as the others $(-0.01 \mathrm{~mm} / \mathrm{s})$, whereas using the crystallographic coordinates results in $\delta=0.47 \mathrm{~mm} / \mathrm{s}$. Geometry optimization of the $S=2$ state for 1-6 leads to minima with much longer $\mathrm{Fe}-\mathrm{N}$ distances $(1.99 \AA)$ and dihedral angles between the ligand planes close to $90^{\circ}$; these metrical parameters are similar to those of the X-ray crystal structure of 6 . The Mössbauer isomer shift at those geometries is $\delta=0.55 \mathrm{~mm} / \mathrm{s}$, which may be taken as reference value for the high-spin state in this series of compounds.

Therefore, we hypothesized that the difference in the data for 6 (low-spin according to Mössbauer spectroscopy vs highspin based on the X-ray crystal structure) may be due to a discrepancy between the properties of 6 in the crystalline state or as a powder. This was evaluated by comparison of the powder X-ray diffraction pattern of a bulk sample of 6 with the simulated pattern based on the single-crystal data. Indeed, the experimental powder diffraction pattern is very different (see Figure S4), confirming that the single-crystal X-ray structure is not representative of the bulk and that packing forces in crystalline $\mathbf{6}$ are responsible for its structure and spin-state being different from the rest of the series.

Additional support for this notion comes from the observation of a mixture of two Fe-containing species in a different batch of 6 : in addition to the low-spin form $(15 \%, \delta=$ $0.03 \mathrm{~mm} / \mathrm{s}$, and $\left.\left|\Delta E_{\mathrm{q}}\right|=1.82 \mathrm{~mm} / \mathrm{s}\right)$, the major species $(85 \%)$ in this sample shows a quadrupole doublet with $\delta=0.60 \mathrm{~mm} / \mathrm{s}$ and $\left|\Delta E_{\mathrm{q}}\right|=0.91 \mathrm{~mm} / \mathrm{s}$. SQUID magnetization data for this sample of 6 gave $\chi_{\mathrm{M}} T=2.55 \mathrm{~cm}^{3} \mathrm{~mol}^{-1} \mathrm{~K}$ in the temperature range $50-300 \mathrm{~K}$, which is consistent with the expected value for a 15:85 mixture of low- and high-spin complex. It should be noted that the Mössbauer parameters for this major species are also in good agreement with the data calculated for high-spin 6 using either the crystallographic coordinates or the optimized quintet geometry. At higher temperature (ca. $390 \mathrm{~K}$ ), the SQUID magnetization increases to $\chi_{\mathrm{M}} T=3.2 \mathrm{~cm}^{3} \mathrm{~mol}^{-1} \mathrm{~K}$, in agreement with transition to a fully high-spin sample. This is also observed in the DSC of 6 (Figure S8), which in the first heating cycle shows an endothermic peak at $397 \mathrm{~K}$. After this transition, subsequent cycling indicates exothermic and endothermic peaks at ca. 333 and $348 \mathrm{~K}$, respectively. Because the SQUID data do not indicate a change in magnetization upon cooling, we ascribe these additional features to a phase transition that does not involve a spin-state change. It should be noted that the temperature of the first transition (LS to HS) is again dependent on crystallinity, and grinding the sample of 6 shifts the transition temperature to $421 \mathrm{~K}$.

Whereas compounds $\mathbf{1 - 4}$ are low-spin in the solid state over the temperature range that is accessible for SQUID measurements (up to $400 \mathrm{~K}$ ), the X-ray data for 5 suggest that its magnetic properties are temperature-dependent. As shown in Figure 3, the SQUID data confirm that this is the case: the magnetic susceptibility increases slowly above ca. $250 \mathrm{~K}$. At $400 \mathrm{~K}$, it reaches a value that corresponds to ca. $40 \%$ population of the $S=2$ state at $400 \mathrm{~K}$, and the process is reversible upon cooling.

Variable-Temperature NMR and UV/Vis Spectroscopy in Solution. To study the spin-crossover behavior in the absence of intermolecular interactions and packing effects in

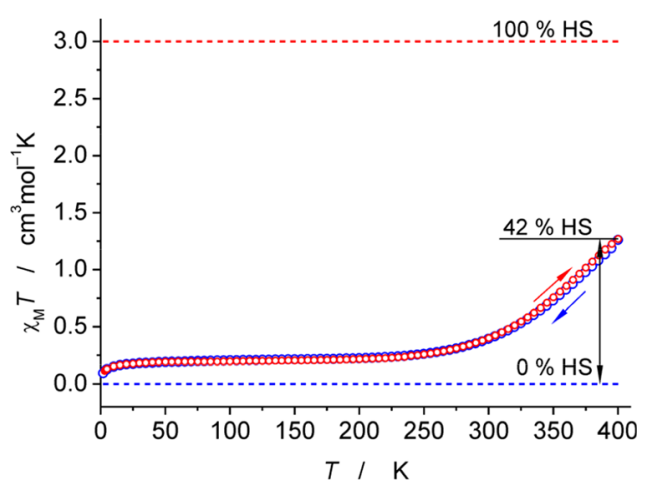

Figure 3. Magnetic susceptibility data for 5 in the solid state. The dashed red and blue lines show spin-only values for $S=2$ and $S=0$ spin states, respectively.

the solid state, we turned our attention to solution-phase studies. ${ }^{1} \mathrm{H}$ NMR spectroscopy at room temperature of compounds 2-6 in THF- $d_{8}$ solution showed the expected number of resonances for a symmetrical bischelate structure in the range between $\delta-10$ and $+20 \mathrm{ppm}$. For all compounds, decreasing the temperature led to a shift of the resonances toward the diamagnetic region (between $\delta-2$ and $+14 \mathrm{ppm}$ ), while at high temperature the signals broaden and are dispersed over a larger chemical shift range (see the Supporting Information). These observations are contrary to the typical Curie behavior expected of a paramagnetic compound but, instead, are in agreement with a temperature-dependent equilibrium between a LS $(S=0)$ diamagnetic state at low temperature and a HS $(S=2)$ paramagnet at high temperature.

Monitoring the changes in the ${ }^{1} \mathrm{H}$ NMR spectrum as a function of temperature allows determination of the thermodynamic parameters for the spin-state equilibrium via eq $1 .^{10 b, 22}$

$$
\delta_{\text {obs }}=\delta_{\mathrm{LS}}+\frac{C}{T\left(1+\mathrm{e}^{(\Delta H / R T)+(\Delta S / R)}\right)}
$$

In our analysis, the Curie constant $(C)$ and the changes in enthalpy $(\Delta H)$ and entropy $(\Delta S)$ are fitting parameters, whereas the chemical shift in the low-spin extreme are either constrained to the value from the lowest temperature NMR data (when the data indicate the low-spin fraction to be close to 1) or estimated from the curve fitting. Excellent fits of the experimental data points are obtained for all compounds (see the Supporting Information), allowing accurate thermodynamic parameters to be extracted (Table 2).

Solution NMR data for 1 were previously reported in toluene- $d_{8}$, but because the solubility of some of the other compounds was significantly better in THF- $d_{8}$, we report here measurements of the entire series in the latter solvent. The difference in enthalpy between the low- and high-spin state of 1 is smaller in THF- $d_{8}\left(\Delta H=18.8(1) \mathrm{kJ} \mathrm{mol}^{-1}\right)$ than it is in toluene- $d_{8}\left(22.2(3) \mathrm{kJ} \mathrm{mol}^{-1}\right)$, but at the same time also the entropy change is lower $\left(\Delta S=54.1(4)\right.$ and $64(1) \mathrm{J} \mathrm{mol}^{-1} \mathrm{~K}^{-1}$ in THF- $d_{8}$ and toluene- $d_{8}$, respectively). Coordination of THF is considered unlikely in these compounds, and we conclude that the (small) variation is due to a difference in dielectric constant of the medium, which leads to changes between solvation of the diamagnetic and paramagnetic states. ${ }^{23}$ Overall, the thermodynamic parameters that describe the equilibrium lead in both solvents to a spin-crossover temperature that is the same within experimental error $\left(T_{1 / 2}\right.$ 
Table 2. Thermodynamic Parameters for the Equilibrium between $S=0$ and $S=2$ Spin States in THF- $d_{8}$ Solution for Compounds 1-6

\begin{tabular}{|c|c|c|c|c|c|c|c|}
\hline & $1^{a}$ & 1 & 2 & 3 & 4 & 5 & 6 \\
\hline$\Delta H\left(\mathrm{~kJ} \mathrm{~mol}{ }^{-1}\right)$ & $22.2 \pm 0.3$ & $18.8 \pm 0.1$ & $27.2 \pm 0.5$ & $8.6 \pm 0.2$ & $17.4 \pm 0.2$ & $20.6 \pm 0.2$ & $17.9 \pm 0.1$ \\
\hline$\Delta S\left(\mathrm{~J} \mathrm{~mol}^{-1} \mathrm{~K}^{-1}\right)$ & $64 \pm 1$ & $54 \pm 1$ & $75 \pm 2$ & $29 \pm 1$ & $50 \pm 1$ & $56 \pm 1$ & $54 \pm 1$ \\
\hline$T_{1 / 2}^{b}(\mathrm{~K})$ & $345 \pm 7$ & $346 \pm 3$ & $361 \pm 12$ & $300 \pm 15$ & $345 \pm 13$ & $368 \pm 5$ & $329 \pm 4$ \\
\hline
\end{tabular}
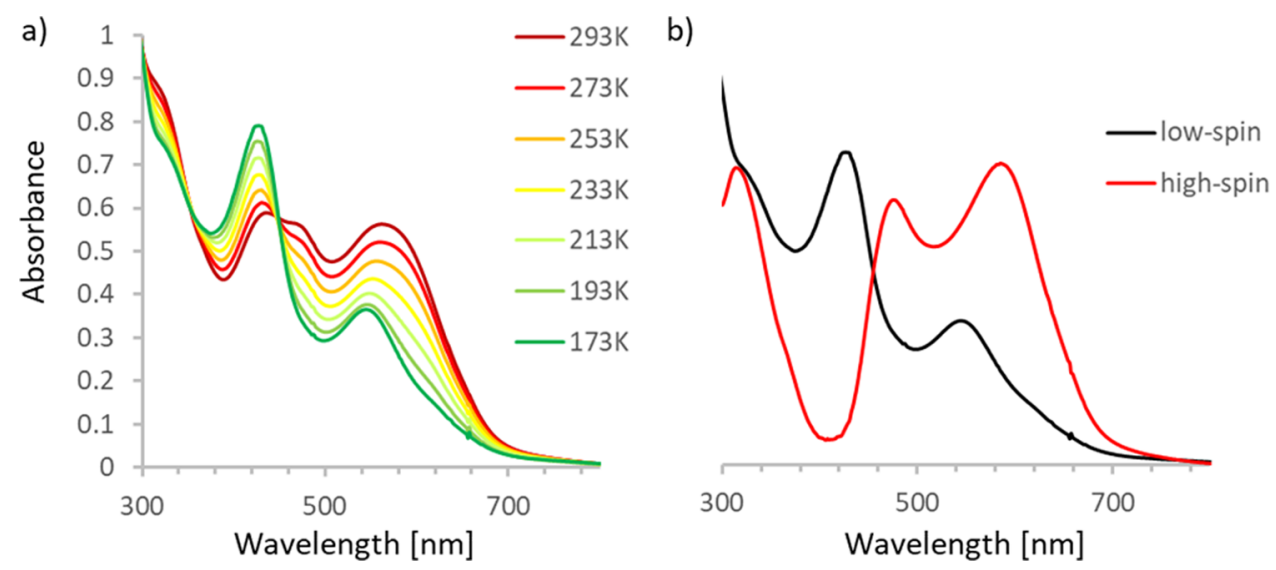

Figure 4. (a) UV/vis spectra for 3 collected in THF solution between 173 and $293 \mathrm{~K}$. (b) Comparison of (normalized) spectral data for the lowspin state $(173 \mathrm{~K})$ and high-spin state (from scaled subtraction of the data at 293 and $173 \mathrm{~K}$ ).

$=345$ and $346 \mathrm{~K}$ ). Despite the distinctly different structural features of $\mathbf{1}$ and $\mathbf{6}$ in the solid state (vide supra), their characterization data in solution are very similar, with $\mathbf{6}$ having a marginally smaller value for $\Delta H\left(17.9(1) \mathrm{kJ} \mathrm{mol}^{-1}\right)$ resulting in a spin-crossover temperature of $329 \mathrm{~K}$. Thus, the effect of the $p$-tolyl group $\left(\mathrm{R}^{\mathrm{C}}=\mathrm{Me}\right)$ on spin-crossover thermodynamics is small.

A comparison of compounds 1-3 allows electronic effects of the $\mathrm{N}-$ Ar groups $\left(\mathrm{Ar}=\mathrm{C}_{6} \mathrm{H}_{4}-\mathrm{p}-\mathrm{R}\right.$, with $\mathrm{R}^{\mathrm{N}}=\mathrm{H}(\mathbf{1}), \mathrm{F}(2)$, and OMe (3)) to be evaluated. ${ }^{24}$ An increase in both $\Delta H$ and $\Delta S$ is observed for the fluoro-substituted compound $2(\Delta H=$ 27.2(5) $\mathrm{kJ} \mathrm{mol}^{-1}$; $\left.\Delta S=75(2) \mathrm{J} \mathrm{mol}^{-1} \mathrm{~K}^{-1}\right)$. Conversely, the electron-donating methoxy group in 3 results in a significant drop of these values to $\Delta H=8.6(2) \mathrm{kJ} \mathrm{mol}^{-1}$ and $\Delta S=29$ (1) $\mathrm{J} \mathrm{mol}^{-1} \mathrm{~K}^{-1}$. As a consequence of these changes, the spincrossover temperature is lower in $3\left(T_{1 / 2}=300 \mathrm{~K}\right)$ than it is in $2\left(T_{1 / 2}=361 \mathrm{~K}\right)$.

To further probe spin-crossover in solution, the temperature dependence of the UV/vis absorption spectra for 2-6 was evaluated in THF (Figure 4 for 3; for others see the Supporting Information). At $173 \mathrm{~K}$, all compounds show two absorption maxima in the visible range: a low-energy feature is observed between 525 and $550 \mathrm{~nm}$, and an additional absorption occurs at around $405-425 \mathrm{~nm}$. These bands are attributed to the low-spin complexes, as this is the predominant form present at this temperature. The high intensity of both bands and the observation that their position does not significantly change with solvent polarity (see Figure S22 for a comparison of UV/vis spectra in toluene, THF, and 1,2-dichloroethane) are indicative of ligand-based $\pi-\pi^{*}$ transitions. Upon warming the UV/vis solutions, the signals broaden due to the appearance of additional spectral features indicating population of the high-spin state. Although at room temperature the spin-crossover is incomplete $(<50 \%)$, difference spectra indicate that the high-spin state has two new absorption maxima that are shifted to lower energy (around
450-475 and 580-590 nm, respectively). For these dilute solutions, further increasing the temperature results in the appearance of decomposition products (loss of isosbestic points) which is likely due to reaction with adventitious air/ moisture. Analysis of the changes in the UV/vis data between 173 and $293 \mathrm{~K}$ gives equilibrium parameters that are in good agreement with those from NMR data, corroborating the trends discussed above (see the Supporting Information for details).

On the basis of these solution characterization data, the following general features emerge. The thermodynamic parameters $(\Delta H$ and $\Delta S)$ that describe the spin equilibrium in this series vary in a manner that is correlated to the nature of the substituent in the para-position (in particular for the N-Ar groups). Despite this variation, the spin-crossover temperatures are found in a relatively narrow range $\left(T_{1 / 2}=300-368\right.$ $\mathrm{K})$. This is due to a linear relationship between $\Delta H$ and $\Delta S$, which leads to a "compensation" effect between enthalpic and entropic contributions to the change in Gibbs free energy (Figure 5). ${ }^{25}$ Literature reports on electronic substituent effects in spin-crossover compounds have shown contradictory results in different series of pseudo-octahedral compounds, depending on whether inductive effects (i.e., on $\sigma$-type metalligand interactions) $)^{10 b, 26}$ or $\pi$-bonding effects ${ }^{27}$ are most important. A recent report on six-coordinate $\mathrm{Fe}(\mathrm{II})$ spincrossover compounds with di(pyrazol-1-yl)pyridine ligands resolved some of these ambiguities by careful consideration of the position of the substituent in the molecule and the relative impact on metal-ligand $\sigma$ - or $\pi$-bonding interactions. ${ }^{28}$ In the compounds discussed here, the largest difference in thermodynamic parameters is between compounds that differ in the $\mathrm{N}-$ Ar substituent (i.e., $\mathbf{2}$ and $\mathbf{3}$ ), with the fluorinated derivative $\mathbf{2}$ having the largest values for $\Delta H$ and $\Delta S$. The opposite trend is found for the $\mathrm{C}-\mathrm{Ar}$ substituents: the fluorinated derivative 4 has a relatively low $\Delta H / \Delta S$. These empirical trends are in agreement with arguments based on a qualitative analysis of 


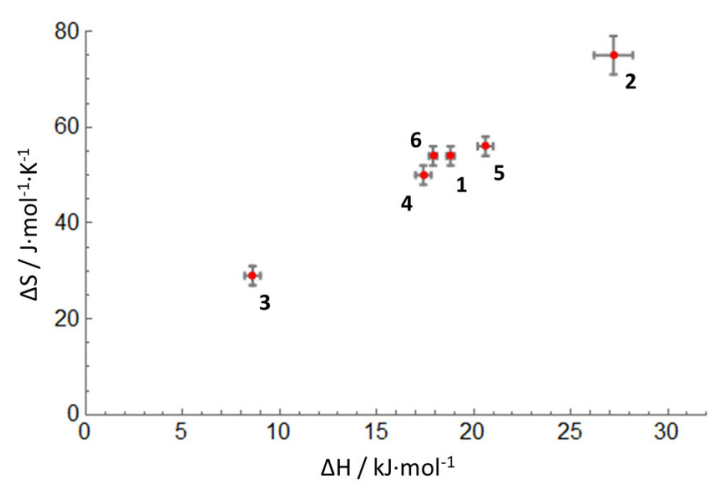

Figure 5. Correlation between $\Delta H$ and $\Delta S$ in compounds 1-6. Error bars are shown as $2 \sigma$ in $\Delta H$ and $\Delta S$.

the MO interactions in these compounds, which indicate that the "flattened" structure of the low-spin state is stabilized due to metal-to-ligand $\left(\mathrm{d} \rightarrow \pi^{*}\right)$ backdonation (Figure 6). ${ }^{14}$ The

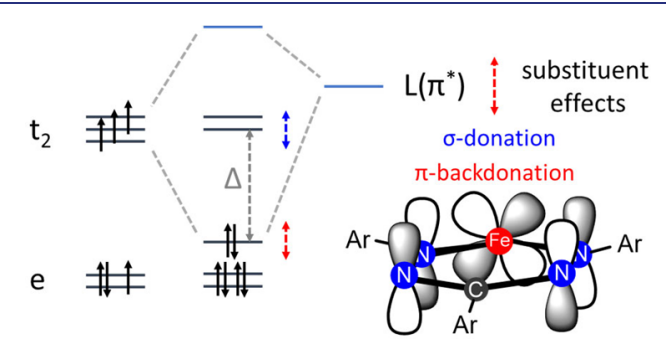

Figure 6. Qualitative MO diagram, showing the $d_{y z} \rightarrow \pi^{*}$ backbonding interaction that stabilizes the low-spin state (only one ligand is shown for clarity).

$\pi$-backbonding interaction lowers one of the d-orbitals (the $d_{y z}$ orbital that belongs to the $t_{2}$ set in a tetrahedral complex) in the low-spin state, while this $\pi$-bonding component is reduced in the quintet state. The para-substituents on the $\mathrm{N}-\mathrm{Ar}$ rings influence the energy of the $\pi^{*}$-acceptor orbital of the formazanate backbone, and as a consequence the $\mathrm{N}-\mathrm{Ar}$ substituents affect the extent of $\pi$-backbonding and thus the stabilization of the low-spin state (Figure 6). On the other hand, the $\mathrm{C}-\mathrm{Ar}$ substituent lies in the nodal plane of the $\pi^{*}$ - orbital, resulting in a much smaller inductive effect that primarily affects the $\sigma$-donor strength.

Computational Studies. To gain insight into the experimentally observed trends for compounds $1-6$, electronic structure calculations at the density functional theory (DFT) level were performed by using Gaussian09. ${ }^{29}$ Using the OPBE functional $^{30}$ with a triple- $\zeta$ basis set with polarization functions $^{31}$ on all atoms, we fully optimized the structures of compounds $1-6$ in both spin states $(S=0$ and $S=2)$. A good agreement for the $\mathrm{Fe}-\mathrm{N}$ bond lengths is observed between the low-spin minima and the crystallographic data for compounds $\mathbf{1}_{\text {calc }}-\mathbf{5}_{\text {calc }}$, while the high-spin DFT geometry of $\boldsymbol{6}_{\text {calc }}$ matches closely with the X-ray structure of $\mathbf{6}$. Similarly, the N-N bond lengths are properly reproduced in the calculations (see Tables S9 and S10). The optimized geometries show an increase of $0.17 \AA$ in the $\mathrm{Fe}-\mathrm{N}$ bonds associated with the $S=0 \rightarrow S=2$ transition, which is accompanied by a smaller decrease of the $\mathrm{N}-\mathrm{N}$ bond lengths. The dihedral angles between the NFeN coordination planes in the low-spin compounds $\mathbf{1 - 5}$ are somewhat larger in the DFT-optimized structures than those determined by X-ray crystallography, but the computed structures do show the "flattened" tetrahedral coordination environments typical for these compounds in the low-spin state. The metrical parameters are virtually identical within the series $\mathbf{1}_{\text {calc }}-\mathbf{5}_{\text {calc }}$, which confirms that the para-substituents only lead to small (electronic) perturbations. We subsequently focused on the thermochemistry for spin-crossover calculated at the DFT level. The computed enthalpy changes $\left(\Delta H_{\text {calc }}\right)$ for the spin-crossover are systematically lower than the empirical data but follow the experimental trends (Figure 7A). An estimation of the corresponding $T_{1 / 2}$ for systems $1-6$ can be done by using the thermochemical quantities, and although the computed values are below the experimental ones, also here the experimental trend is properly reproduced (see Table S13). A scan of the potential energy surface with variation of the dihedral angle between the NFeN coordination planes shows that in both spin states the PES is relatively flat around the minima, with changes in the dihedral angle of $\pm 10^{\circ}$ only associated with a $<5 \mathrm{~kJ} \mathrm{~mol}^{-1}$ increase in the electronic energy. The two energy curves show that at the low-spin minimum the energy of the high-spin state lies ca. $45 \mathrm{~kJ} \mathrm{~mol}^{-1}$ above, and the
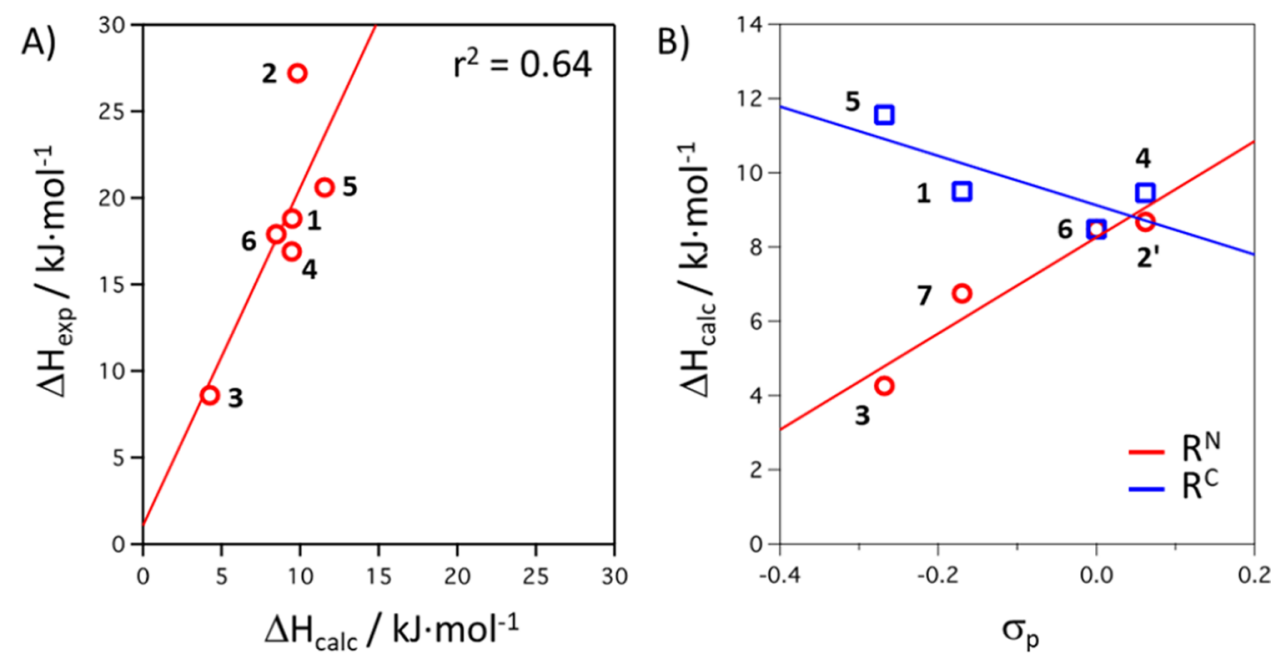

Figure 7. (A) Plot of DFT-calculated vs experimental $\Delta H$ values for the equilibrium between low- and high-spin states in 1-6. (B) Plot of $\Delta H_{\text {calc }}$ vs the Hammett parameter $\sigma_{\mathrm{p}}$ for para-substituents at either the $\mathrm{N}-\mathrm{Ar}\left(\mathrm{R}^{\mathrm{N}}\right)$ or the $\mathrm{C}-\mathrm{Ar}\left(\mathrm{R}^{\mathrm{C}}\right)$ position. 
two spin states intersect at an interplanar angle of ca. $90^{\circ}$ (Figure S58).

To explain the trends in spin-crossover thermodynamics, we subsequently focused on identifying the origin of substituent effects $\left(\mathrm{R}^{\mathrm{N}}\right.$ and $\left.\mathrm{R}^{\mathrm{C}}\right)$ on the enthalpy differences $(\Delta H)$ in the series. If the spin-crossover properties in these complexes are governed by stabilization of the $\mathrm{d}_{y z}$ orbital due to $\pi$ backdonation, ${ }^{14}$ a correlation is expected between the Hammett parameter $\sigma_{\mathrm{p}}$ of the $\mathrm{N}-\mathrm{Ar}$ substituent $\left(\mathrm{R}^{\mathrm{N}}\right)$ and the enthalpy term $\Delta H$ for the spin-state equilibrium. We modeled the $\mathrm{C}-\mathrm{Ar}$ and $\mathrm{N}-\mathrm{Ar}$ substitution independently; that is, 2 is replaced with $2^{\prime}\left(\mathrm{R}^{\mathrm{N}}=\mathrm{F}, \mathrm{R}^{\mathrm{C}}=\mathrm{H}\right)$ and $7\left(\mathrm{R}^{\mathrm{N}}=\mathrm{Me}, \mathrm{R}^{\mathrm{C}}\right.$ $=\mathrm{H})$ is added to the series. A plot of $\Delta H_{\text {calc }}$ vs $\sigma_{\mathrm{p}}$ for complexes with different $\mathrm{R}^{\mathrm{N}}$ substituents shows that increasing its electron-withdrawing ability indeed leads to larger values for $\Delta H_{\text {calc }}$, while the opposite effect is seen for the C-Ar parasubstituent $\left(\mathrm{R}^{\mathrm{C}}\right.$, Figure $\left.7 \mathrm{~B}\right)$. Although the calculated LS-HS energy differences are small in this series (on the order of a few $\mathrm{kJ} / \mathrm{mol}$ ), the results are in qualitative agreement with basic ligand field arguments: the $\mathrm{R}^{\mathrm{N}}$ substituent primarily influences $\mathrm{M}-\mathrm{L} \pi$-bonding whereas $\mathrm{R}^{\mathrm{C}}$ has an inductive effect on the $\mathrm{M}-$ L $\sigma$-bonds.

A comparison of the frontier orbitals shows that the $\mathrm{R}^{\mathrm{N}}$ group has the expected effect on the absolute energies of all frontier orbitals via electron-donation/withdrawal, but the relative energies are similar and the orbital splitting changes only slightly. Although the low symmetry in these compounds does not result in the familiar, (near-)degenerate $t+e$ splitting of the d-orbitals, the DFT calculations show a "two-over-three" pattern that is very similar across the series, with a relatively small HOMO-LUMO gap that varies between $9672 \mathrm{~cm}^{-1}\left(\mathrm{R}^{\mathrm{N}}\right.$ $=\mathrm{OMe})$ and $9936 \mathrm{~cm}^{-1}\left(\mathrm{R}^{\mathrm{N}}=\mathrm{F}\right)$. In contrast to typical octahedral $\mathrm{Fe}$ (II) spin-crossover compounds, as well as the four-coordinate $\mathrm{Fe}$ (II) complexes of Smith et al. (>26000 $\left.\mathrm{cm}^{-1}\right),{ }^{32}$ these energy gaps are very small and would not normally be associated with spin-crossover behavior. However, the large degree of covalency in the $\mathrm{Fe}-\mathrm{N}$ bonds in bis(formazanate) iron complexes apparently leads to low interelectronic repulsion through the nephelauxetic effect, favoring the low-spin state. This is further corroborated by intrinsic bond orbital (IBO) analysis. IBOs allow interpretation of the wave function in terms of localized orbitals that provide a chemically intuitive connection with classical (Lewis-type) bonding. ${ }^{33}$ Analysis of the IBOs at the iron center in low-spin $\mathbf{6}_{\text {calc }}$ reveals three occupied orbitals that have d-character. Two of these are $\pi$-bonding with the ligand as shown by substantial delocalization onto the formazanate $\mathrm{N}$ atoms, reflected in the relative charge contributions of the $\mathrm{Fe}$ and $\mathrm{N}$ centers to the overall orbital occupation (Figure 8 ). The IBOs are insensitive to substituent effects (both for $\mathrm{R}^{\mathrm{N}}$ and $\mathrm{R}^{\mathrm{C}}$ ), which implies that covalent $\mathrm{Fe}-\mathrm{N} \pi$-bonding causes the unusual d-orbital splitting pattern but is not modulated significantly by the $\mathrm{R}^{\mathrm{N}}$ or $\mathrm{R}^{\mathrm{C}}$ substituents.

Focusing on the compounds that are shown experimentally to differ the most, i.e., 2 and $\mathbf{3}$, it is clear that a simplistic explanation based on substituent effects to the ligand-field strength is insufficient to explain the difference in $\Delta H$ of 18.6 $\mathrm{kJ} / \mathrm{mol}$ : there is only a difference of $\sim 250 \mathrm{~cm}^{-1}$ in the orbital splitting energies between the two at the DFT level. However, this discrepancy is perhaps not surprising because there are multiple additional contributions that determine spin-crossover thermochemistry (e.g., geometry relaxation and vibrational entropy terms). ${ }^{25 \mathrm{~b}}$ Regardless, the DFT calculations can

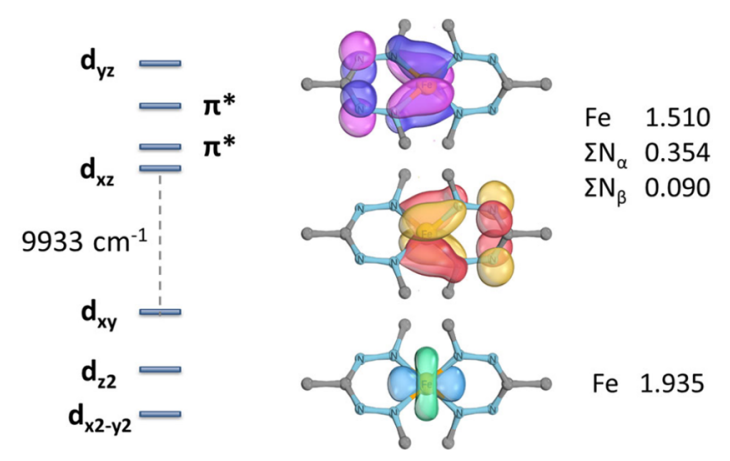

Figure 8. Energy diagram of the frontier orbitals in low-spin bis(formazanate) iron complexes (left) and IBOs with major contribution from the Fe d-orbitals (right; Ar groups omitted for clarity). Values given are the charge contributions of the relevant atoms.

capture the trends for the compounds studied here in a qualitatively correct manner. Similar to iron(II) complexes with 2,6-di(pyrazol-1-yl)pyridine ligands, ${ }^{28}$ the different influence of $\mathrm{R}^{\mathrm{C}}$ and $\mathrm{R}^{\mathrm{N}}$ substituents suggests that both $\mathrm{Fe}-\mathrm{L}$ $\sigma$ - and $\pi$-bonding effects are involved, which have an opposing influence on spin-crossover properties.

\section{CONCLUSIONS}

We have demonstrated that spin-crossover in bis(formazanate) iron(II) complexes is a general feature of this class of compounds. Characterization in the solid state shows that changes in ligand substituents can affect packing forces such that the preference for a more compact low-spin state can be overridden in favor of high-spin, which can be extended to include an example (complex 5) that has sufficient plasticity in the solid state to undergo a gradual, reversible spin transition. In the absence of packing effects, the spin-crossover behavior in solution shows that the thermodynamic values are sensitive to substituent effects, but the high degree of correlation between $\Delta H$ and $\Delta S$ results in transition temperatures $\left(T_{1 / 2}\right)$ that are between 300 and $368 \mathrm{~K}$. The most significant differences are observed for compounds 2 and 3, which can be ascribed to the electronic nature of the para-substituent at the $\mathrm{N}-\mathrm{Ar}$ ring $\left(\mathrm{R}^{\mathrm{N}}\right)$. The effect of the $\mathrm{R}^{\mathrm{N}}$ and $\mathrm{R}^{\mathrm{C}}$ substituents on spin-crossover thermodynamics is found to be in the opposite direction, which is related to the competing influence of the substituents $\mathrm{R}^{\mathrm{N}} / \mathrm{R}^{\mathrm{C}}$ on metal-ligand $\sigma$ - and $\pi$-bonding. More generally, this study provides insight into how the enthalpy and entropy contributions to the spin-state energetics can be manipulated in this class of compounds, but the observed correlation between $\Delta H$ and $\Delta S$ results in spin-crossover temperatures that are remarkably similar. Extension of this work to break this correlation and obtain a wider range of spincrossover temperatures will likely require more extensive ligand modifications, for instance through steric effects. Overall, this work provides general access to a novel class of low-coordinate $\mathrm{Fe}(\mathrm{II})$ complexes that reliably yield spin-crossover behavior by virtue of the metal-ligand $\pi$-covalency. This feature may be more generally applicable to the stabilization of first-row metal complexes in their low-spin state, which we anticipate to be useful in understanding the influence of spin state on reactivity.

\section{EXPERIMENTAL SECTION}

Synthesis of $\mathrm{Fe}\left[\left(\mathrm{C}_{6} \mathrm{H}_{4}(p-\mathrm{F})\right) \mathrm{NNC}(p-\mathrm{Tol}) \mathrm{NN}\left(\mathrm{C}_{6} \mathrm{H}_{4}(p-\mathrm{F})\right)\right]_{2}$ (2). A red THF $(15 \mathrm{~mL})$ solution of $\mathbf{L} 2 \mathrm{H}(439.4 \mathrm{mg}, 1.26 \mathrm{mmol})$ was added 
to a green solution of $\mathrm{Fe}\left[\mathrm{N}\left(\mathrm{SiMe}_{3}\right)_{2}\right]_{2}(236.3 \mathrm{mg}, 0.63 \mathrm{mmol})$ in 10 $\mathrm{mL}$ of THF. The reaction mixture was stirred for 1 day at room temperature, leading to a dark red solution. The volatiles were removed under vacuum. The product was extracted into THF, and slow diffusion of hexane into the THF solution afforded 2 as dark crystalline material $(419.9 \mathrm{mg}, 0.52 \mathrm{mmol}, 83 \%) .{ }^{1} \mathrm{H}$ NMR (400 $\mathrm{MHz}$, THF- $\left.d_{8}, 25{ }^{\circ} \mathrm{C}\right): \delta 9.08\left(4 \mathrm{H}, \mathrm{C}_{6} \mathrm{H}_{4}(p-\mathrm{F}) m-\mathrm{CH}\right), 8.88(2 \mathrm{H}, p-$ Tol $m-\mathrm{CH}), 6.67(2 \mathrm{H}, p-\mathrm{Tol} o-\mathrm{CH}), 5.50(3 \mathrm{H}, p-\mathrm{Tol} \mathrm{CH}), 3.71(\mathrm{~m}$, THF)* 3.85 (br, $\left.4 \mathrm{H}, \mathrm{C}_{6} \mathrm{H}_{4}(p-\mathrm{F}) o-\mathrm{CH}\right), 1.87$ (m, THF)* ppm. ${ }^{1} \mathrm{H}$ NMR $\left(500 \mathrm{MHz}\right.$, THF- $\left.d_{8},-70{ }^{\circ} \mathrm{C}\right): \delta 8.29(2 \mathrm{H}, p$-Tol $o$-CH), 7.35 $(2 \mathrm{H}, p-\mathrm{Tol} m-\mathrm{CH}), 7.02\left(4 \mathrm{H} \mathrm{C}_{6} \mathrm{H}_{4}(p-\mathrm{F}) m-\mathrm{CH}\right), 6.52\left(4 \mathrm{H}, \mathrm{C}_{6} \mathrm{H}_{4}(p-\right.$ F) $o-\mathrm{CH}), 3.62(\mathrm{~m}, \mathrm{THF}) * 2.41\left(3 \mathrm{H}, p-\mathrm{Tol} \mathrm{CH}_{3}\right), 1.79(\mathrm{~m}, \mathrm{THF}) *$ ppm. ${ }^{19} \mathrm{~F}$ NMR (470 MHz, THF- $\left.d_{8},-70{ }^{\circ} \mathrm{C}\right): \delta-115.40 \mathrm{ppm} .{ }^{13} \mathrm{C}$ NMR $\left(126 \mathrm{MHz}\right.$, THF- $\left.d_{8},-70{ }^{\circ} \mathrm{C}\right): \delta 163.7\left(\mathrm{~d},{ }^{1} J_{\mathrm{C}-\mathrm{F}}=247 \mathrm{~Hz}\right.$, $\mathrm{C}_{6} \mathrm{H}_{4}(p-\mathrm{F})$ ipso $\left.\mathrm{C}-\mathrm{F}\right), 162.5\left(\mathrm{br}^{\ddagger}, \mathrm{C}_{6} \mathrm{H}_{4}(p-\mathrm{F})\right.$ ipso $\left.\mathrm{C}-\mathrm{C}\right), 147.7$ (ipso $\mathrm{N}-\mathrm{C}=\mathrm{N}), 140.3\left(p\right.$-Tol ipso $\left.\mathrm{C}-\mathrm{CH}_{3}\right), 135.9$ ( $p$-Tol ipso $\left.\mathrm{C}-\mathrm{C}\right)$, $130.3(p$-Tol $m-\mathrm{CH}), 128.3(p$-Tol $o-\mathrm{CH}), 127.0\left(\mathrm{~d},{ }^{3} J_{\mathrm{C}-\mathrm{F}}=6 \mathrm{~Hz}\right.$, $\left.\mathrm{C}_{6} \mathrm{H}_{4}(p-\mathrm{F}) o-\mathrm{CH}\right), 115.8\left(\mathrm{~d},{ }^{2} \mathrm{~J}_{\mathrm{C}-\mathrm{F}}=23 \mathrm{~Hz}, \mathrm{C}_{6} \mathrm{H}_{4}(p-\mathrm{F}) m-\mathrm{CH}\right), 21.6$ $\left(p\right.$-Tol $\left.\mathrm{CH}_{3}\right)$ ppm. *Crystals of 2 contain 1.5 THF per iron complex based on the SQUEEZE results (120 electrons per unit cell). Based on integration of the ${ }^{1} \mathrm{H}$ NMR spectrum of 2 in $\mathrm{C}_{6} \mathrm{D}_{6}$, the bulk sample contains ca. 0.75 THF per iron complex. ${ }^{+}$The peak is broad due to ${ }^{4} J_{\mathrm{C}-\mathrm{F}}$. Anal. Calcd for $\mathrm{C}_{43} \mathrm{H}_{36} \mathrm{~N}_{8} \mathrm{~F}_{4} \mathrm{O}_{0.75} \mathrm{Fe}$ : C, 63.87; H, 4.49; $\mathrm{N}, 13.86$. Found: C, 64.14; H 4.33; N, 14.00 .

Synthesis of $\mathrm{Fe}[(p-\mathrm{An}) \mathrm{NNC}(\mathrm{Ph}) \mathrm{NN}(p-\mathrm{An})]_{2}$ (3). A fuchsia THF $(15 \mathrm{~mL})$ solution of $\mathrm{L} 3 \mathrm{H}(421.8 \mathrm{mg}, 1.17 \mathrm{mmol})$ was added to a green solution of $\mathrm{Fe}\left[\mathrm{N}\left(\mathrm{SiMe}_{3}\right)_{2}\right]_{2}(220.4 \mathrm{mg}, 0.59 \mathrm{mmol})$ in $10 \mathrm{~mL}$ of THF. The reaction mixture was stirred for 1 day at room temperature, leading to a dark plum-colored solution. The volatiles were removed under vacuum. The product was extracted into THF, and slow diffusion of hexane into the THF solution afforded 3 as dark powder ( $322.9 \mathrm{mg}, 0.42 \mathrm{mmol}, 71 \%$ ). Single crystals suitable for X-ray analysis were obtained by slow diffusion of hexane into a THF solution. ${ }^{1} \mathrm{H}$ NMR ( $500 \mathrm{MHz}$, THF- $\left.d_{8}, 25^{\circ} \mathrm{C}\right): \delta 19.31(4 \mathrm{H}, p$-An $m$-CH), 17.06 $(2 \mathrm{H}, \mathrm{Ph} m-\mathrm{CH}), 3.88(\mathrm{~m}, \mathrm{THF}) *, 3.76\left(6 \mathrm{H}, p-\mathrm{An} \mathrm{OCH}_{3}\right), 2.51(1 \mathrm{H}$, $\mathrm{Ph} p-\mathrm{CH}),-1.52(2 \mathrm{H}, \mathrm{Ph} o-\mathrm{CH}), 2.01$ (m, THF)*, $-6.80(2 \mathrm{H} p-\mathrm{An}$ $\left.o-\mathrm{CH}^{\mathrm{A}}\right),-8.20\left(2 \mathrm{H} p\right.$-An $\left.o-\mathrm{CH}^{\mathrm{B}}\right)$ ppm. ${ }^{1} \mathrm{H}$ NMR $\left(500 \mathrm{MHz}\right.$, THF- $d_{8}$, $\left.-70{ }^{\circ} \mathrm{C}\right): 12.97(4 \mathrm{H}, p-\mathrm{An} m-\mathrm{CH}), 12.52(2 \mathrm{H}, \mathrm{Ph} m-\mathrm{CH}), 4.40(2 \mathrm{H}$, $\mathrm{Ph} o-\mathrm{CH}), 3.51\left(6 \mathrm{H}, p-\mathrm{An} \mathrm{OCH}_{3}\right), 3.07(1 \mathrm{H}, \mathrm{Ph} p-\mathrm{CH}), 0.74(2 \mathrm{H} p-$ An $\left.o-\mathrm{CH}^{\mathrm{A}}\right),-0.08\left(2 \mathrm{H} p\right.$-An $\left.o-\mathrm{CH}^{\mathrm{B}}\right) \mathrm{ppm}$. Attempts to obtain ${ }^{13} \mathrm{C}$ NMR data were unsuccessful due to the presence of the high-spin form at $-70{ }^{\circ} \mathrm{C}$. *The integration of the peaks of the solvate molecules in the ${ }^{1} \mathrm{H}$ NMR spectrum of 3 in $\mathrm{C}_{6} \mathrm{D}_{6}$ indicates $0.25 \mathrm{THF}$ per iron complex. Anal. Calcd for $\mathrm{C}_{44} \mathrm{H}_{42} \mathrm{~N}_{8} \mathrm{O}_{4.5} \mathrm{Fe}$ : C, 65.19; H, 5.22; $\mathrm{N}, 13.82$. Found: C, 64.74; $\mathrm{H} 5.10 ; \mathrm{N}, 13.30$.

Synthesis of Fe[PhNNC( $\left.\left(\mathrm{C}_{6} \mathrm{H}_{4}(p-\mathrm{F})\right) \mathrm{NNPh}\right]_{2}$ (4). A red THF (15 $\mathrm{mL}$ ) solution of $\mathbf{L} 4 \mathbf{H}(401.7 \mathrm{mg}, 1.26 \mathrm{mmol}$ ) was added to a green solution of $\mathrm{Fe}\left[\mathrm{N}\left(\mathrm{SiMe}_{3}\right)_{2}\right]_{2}(237.6 \mathrm{mg}, 0.63 \mathrm{mmol})$ in $10 \mathrm{~mL}$ of THF. The reaction mixture was stirred overnight at room temperature, leading to a dark red solution. The volatiles were removed under vacuum. The product was extracted into THF, and slow diffusion of hexane into the THF solution afforded 4 as dark red powder $(333.7$ $\mathrm{mg}, 0.48 \mathrm{mmol}, 77 \%)$. Single crystals suitable for X-ray analysis were obtained by slow diffusion at room temperature of hexane into a THF solution. ${ }^{1} \mathrm{H}$ NMR $\left(500 \mathrm{MHz}\right.$, THF- $\left.d_{8}, 25{ }^{\circ} \mathrm{C}\right): \delta 15.53(4 \mathrm{H}, \mathrm{Ph} m-$ $\mathrm{CH}), 12.46\left(2 \mathrm{H}, \mathrm{C}_{6} \mathrm{H}_{4}(p-\mathrm{F}) m-\mathrm{CH}\right), 3.43\left(2 \mathrm{H} \mathrm{C}_{6} \mathrm{H}_{4}(p-\mathrm{F}) o-\mathrm{CH}\right)$, $0.99(2 \mathrm{H}, \mathrm{Ph} p-\mathrm{CH}),-0.97$ (br, Ph $o-\mathrm{CH}) \mathrm{ppm} .{ }^{1} \mathrm{H}$ NMR $(500 \mathrm{MHz}$, THF- $\left.d_{8},-65^{\circ} \mathrm{C}\right): \delta 7.98\left(4 \mathrm{H}, \mathrm{C}_{6} \mathrm{H}_{4}(p-\mathrm{F}) m-\mathrm{CH}\right.$ and $\left.p-\mathrm{CH}\right), 7.89$ $(4 \mathrm{H}, \mathrm{Ph} m-\mathrm{CH}), 6.66(2 \mathrm{H}, \mathrm{Ph} p-\mathrm{CH}), 5.60(4 \mathrm{H}, \mathrm{Ph} o-\mathrm{CH}) \mathrm{ppm} .{ }^{19} \mathrm{~F}$ NMR $\left(470 \mathrm{MHz}\right.$, THF- $\left.d_{8},-65^{\circ} \mathrm{C}\right): \delta-111.30 \mathrm{ppm} .{ }^{13} \mathrm{C}$ NMR $(126$ $\left.\mathrm{MHz}, \mathrm{THF}-d_{8},-65{ }^{\circ} \mathrm{C}\right): \delta 205.6$ (ipso) $170.9\left(\mathrm{~d},{ }^{1} J_{\mathrm{C}-\mathrm{F}}=247 \mathrm{~Hz}\right.$, $\mathrm{C}_{6} \mathrm{H}_{4}(p-\mathrm{F})$ ipso $\left.\mathrm{C}-\mathrm{F}\right), 147.3(\mathrm{Ph} o-\mathrm{CH}), 139.8\left(\mathrm{br}^{\frac{F}{2}}, \mathrm{C}_{6} \mathrm{H}_{4}(p-\mathrm{F}) o-\right.$ $\mathrm{CH}), 136.0(\mathrm{Ph} p-\mathrm{CH}), 128.16$ ( $\mathrm{Ph} m-\mathrm{CH}), 125.9$ (ipso), 112.5 (d, $\left.{ }^{2} J_{\mathrm{C}-\mathrm{F}}=23 \mathrm{~Hz}, \mathrm{C}_{6} \mathrm{H}_{4}(p-\mathrm{F}) m-\mathrm{CH}\right)$ ppm. ${ }^{\ddagger}$ The peak is broad due to ${ }^{3} J_{\mathrm{C}-\mathrm{F}}$. Anal. Calcd for $\mathrm{C}_{38} \mathrm{H}_{28} \mathrm{~N}_{8} \mathrm{~F}_{2} \mathrm{Fe}$ : C, 66.10; H, 4.09; N, 16,23. Found: C, 65.18; H 4.04; N, 15.36.

Synthesis of Fe[PhNNC(p-An)NNPh] $]_{2}$ (5). A fuchsia THF (15 $\mathrm{mL})$ solution of $\mathbf{L 5 H}(643.4 \mathrm{mg}, 2.0 \mathrm{mmol})$ was added to a green solution of $\mathrm{Fe}\left[\mathrm{N}\left(\mathrm{SiMe}_{3}\right)_{2}\right]_{2}(376.5 \mathrm{mg}, 1.0 \mathrm{mmol})$ in $10 \mathrm{~mL}$ of THF. The reaction mixture was stirred overnight at room temperature, leading to a wine-colored solution. The volatiles were removed under vacuum. The product was extracted into THF, and slow diffusion of pentane into the THF solution afforded dark red crystals of 5 (571.5 $\mathrm{mg}, 0.8 \mathrm{mmol}, 80 \%) .{ }^{1} \mathrm{H}$ NMR $\left(500 \mathrm{MHz}\right.$, THF- $\left.d_{8}, 25{ }^{\circ} \mathrm{C}\right): \delta 10.61$ (4H, Ph $m-\mathrm{CH}), 9.77$ (2H, $p$-An $m-\mathrm{CH}), 5.53$ (2H $p$-An $o-\mathrm{CH}), 4.92$ $\left(3 \mathrm{H}, p-\mathrm{An}_{\mathrm{OCH}}\right), 3.81$ (m, THF)*, $3.47(2 \mathrm{H}, \mathrm{Ph} p-\mathrm{CH}), 2.5-1.5$ (br, Ph o-CH), 1.97 (m, THF)* ppm. ${ }^{1} \mathrm{H}$ NMR $\left(500 \mathrm{MHz}, \mathrm{THF}-d_{8}\right.$, $\left.-70{ }^{\circ} \mathrm{C}\right): 8.27(2 \mathrm{H}, p$-An $o-\mathrm{CH}), 7.36(4 \mathrm{H}, \mathrm{Ph} m-\mathrm{CH}), 7.29(2 \mathrm{H}, p-$ An $m-\mathrm{CH}), 7.16(2 \mathrm{H}, \mathrm{Ph} p-\mathrm{CH}), 6.24(4 \mathrm{H}, \mathrm{Ph} o-\mathrm{CH}), 3.98(3 \mathrm{H}, p-$ $\left.\mathrm{An} \mathrm{OCH}_{3}\right), 3.69$ (m, THF)*, 1.86 (m, THF)*. ${ }^{13} \mathrm{C}$ NMR $(126 \mathrm{MHz}$, THF- $d_{8},-70{ }^{\circ} \mathrm{C}$ ): $\delta 185.7$ (ipso), 164.3 (ipso), 163.3 (p-An ipso C$\left.\mathrm{OCH}_{3}\right), 132.2(p-\mathrm{An} o-\mathrm{CH}), 131.5(\mathrm{Ph} o-\mathrm{CH}), 130.6(\mathrm{Ph} p-\mathrm{CH})$, $128.6(\mathrm{Ph} m-\mathrm{CH}), 113.6(p-\mathrm{An} m-\mathrm{CH}), 55.7\left(p-\mathrm{An} \mathrm{OCH}_{3}\right) \mathrm{ppm}$. *Crystals of 5 contain 0.5 THF per iron complex. The integration of the peaks of the solvate molecules in the ${ }^{1} \mathrm{H}$ NMR spectrum of 5 in $\mathrm{C}_{6} \mathrm{D}_{6}$ indicates 0.4 THF per iron complex. Anal. Calcd for $\mathrm{C}_{42} \mathrm{H}_{38} \mathrm{~N}_{8} \mathrm{O}_{2.5} \mathrm{Fe}$ : C, 67.20; H, 5.10; N, 14.93. Found: C, 66.85; $\mathrm{H}$ 5.03; N, 14.69.

Synthesis of $\mathrm{Fe}[(\mathrm{Ph}) \mathrm{NNC}(\mathrm{Ph}) \mathrm{NN}(\mathrm{Ph})]_{2}(6)$. A red THF $(15 \mathrm{~mL})$ solution of $\mathbf{L 6 H}(454.0 \mathrm{mg}, 1.51 \mathrm{mmol})$ was added to a green solution of $\mathrm{Fe}\left[\mathrm{N}\left(\mathrm{SiMe}_{3}\right)_{2}\right]_{2}(283.9 \mathrm{mg}, 0.75 \mathrm{mmol})$ in $10 \mathrm{~mL}$ of THF. The reaction mixture was stirred for 1 day at room temperature, leading to a dark red solution. The solution was filtered, and the volatiles were removed under vacuum. The solid was washed with cold hexane to afford 6 as dark red powder $(422.1 \mathrm{mg}, 0.65 \mathrm{mmol}$, $86 \%$ yield). Single crystal suitable for X-ray analysis were obtained by slow diffusion of hexane into a THF solution at $-30{ }^{\circ} \mathrm{C} .{ }^{1} \mathrm{H}$ NMR $\left(500 \mathrm{MHz}, \mathrm{THF}-d_{8}, 25^{\circ} \mathrm{C}\right): \delta 14.09(4 \mathrm{H}, \mathrm{N}-\mathrm{Ph} m-\mathrm{CH}), 13.16,(2 \mathrm{H}$, C-Ph $m$-CH), 3.09 (2H, C-Ph $o-\mathrm{CH}), 0.26$ (2H, N-Ph $p-\mathrm{CH}), 0.15$ $(1 \mathrm{H}, \mathrm{C}-\mathrm{Ph} p-\mathrm{CH}),-1.78(\mathrm{br}, 4 \mathrm{H}, \mathrm{N}-\mathrm{Ph} o-\mathrm{CH}) \mathrm{ppm} .{ }^{1} \mathrm{H}$ NMR $(500$ MHz, THF- $\left.d_{8},-65{ }^{\circ} \mathrm{C}\right): \delta 8.30(2 \mathrm{H}, \mathrm{C}-\mathrm{Ph} m-\mathrm{CH}), 8.02(4 \mathrm{H}, \mathrm{N}-\mathrm{Ph}$ $m$-CH), $7.91(2 \mathrm{H}, \mathrm{C}-\mathrm{Ph} o-\mathrm{CH}), 6.60(1 \mathrm{H}, \mathrm{C}-\mathrm{Ph} p-\mathrm{CH}), 6.54(2 \mathrm{H}, \mathrm{N}-$ $\mathrm{Ph} p-\mathrm{CH}), 5.48$ (br, 4H, N-Ph $o-\mathrm{CH})$ ppm. ${ }^{13} \mathrm{C}$ NMR $(126 \mathrm{MHz}$, THF- $\left.d_{8},-65^{\circ} \mathrm{C}\right): \delta 150.9(\mathrm{~N}-\mathrm{Ph} o-\mathrm{CH}), 139.3(\mathrm{C}-\mathrm{Ph} o-\mathrm{CH}), 137.0$ (C-Ph $p$-CH and N-Ph $p$-CH), 129.0 (N-Ph $m$-CH), 125.1 (C-Ph $m$ $\mathrm{CH})$ ppm. ${ }^{*}$ The integration of the peaks of the solvate molecules in the ${ }^{1} \mathrm{H}$ NMR spectrum of 6 in $\mathrm{C}_{6} \mathrm{D}_{6}$ indicates 0.3 THF per iron complex. Anal. Calcd for $\mathrm{C}_{39.2} \mathrm{H}_{32.4} \mathrm{~N}_{8} \mathrm{O}_{0.3} \mathrm{Fe}$ : C, 69.63; H, 4.83; N, 16.57. Found: C, 68.92; H 4.48; N, 15.29 .

X-ray Crystallography. Single crystals of compounds 2-6 (directly obtained from the mother liquor) were mounted on top of a cryoloop and transferred into the cold nitrogen stream $(100 \mathrm{~K})$ of a Bruker-AXS D8 Venture diffractometer. Data collection and reduction were done by using the Bruker software suite APEX3. ${ }^{34}$ The final unit cell was obtained from the $x y z$ centroids of 9985 (2), 4635 (3), 9252 (4), 9634 (5), and 9855 (6) reflections after integration. A multiscan absorption correction was applied based on the intensities of symmetry-related reflections measured at different angular settings (SADABS). The structures were solved by direct methods using SHELXS, ${ }^{35}$ and refinement of the structure was performed by using SHLELXL. ${ }^{36}$ For compound 2, refinement was frustrated by the presence of disordered solvent molecules located in two different voids. Attempts to model the electron density allowed identification of THF as the most likely solvate, but the extent of disorder was such that the contribution from these parts of the structure were removed by using the PLATON/SQUEEZE routine. ${ }^{37}$ For compounds 3 and 4 , inspection of the diffraction images and attempts to index the spots indicated it to be twinned. The two orientation matrices of the unit cell were determined by using CELL_NOW. ${ }^{38}$ After integration of the data with these two unit cell orientations, an absorption correction was performed with TWINABS. ${ }^{39}$ Initial structure solution was performed with the HKLF4 file; subsequent refinement used the HKLF5 file. For compound $\mathbf{5}$, refinement indicated the presence of a THF molecule that was disordered over an inversion center. The contribution of this solvate molecule was removed by the PLATON/SQUEEZE routine. ${ }^{37}$ An additional disorder was indicated by the highly anisotropic displacement parameters of four carbon atoms in one of the $\mathrm{N}-\mathrm{C}_{6} \mathrm{H}_{5}$ rings in the ligand. A three-site disorder model was applied to describe the rotational disorder of this group. The site-occupancy factors of these 
three components refined to $0.42,0.38$, and 0.20 . RIGU instructions were used for the disordered phenyl ring to prevent some atoms from obtaining nonpositive definite displacement parameters. For all structures, the hydrogen atoms were generated by geometrical considerations, constrained to idealized geometries and allowed to ride on their carrier atoms with an isotropic displacement parameter related to the equivalent displacement parameter of their carrier atoms. Crystal data and details on data collection and refinement are presented in Tables S2 and S4.

\section{ASSOCIATED CONTENT}

\section{(s) Supporting Information}

The Supporting Information is available free of charge at https://pubs.acs.org/doi/10.1021/jacs.0c10010.

Full experimental and characterization data, computational details (PDF)

Crystallographic data for compounds 2-6 (CIF) Crystallographic data for the variable-temperature study of compound 5 (CIF)

\section{AUTHOR INFORMATION}

\section{Corresponding Author}

Edwin Otten - Stratingh Institute for Chemistry, University of Groningen, 9747 AG Groningen, The Netherlands; 다이.org/0000-0002-5905-5108; Email: edwin.otten@ rug.nl

\section{Authors}

Francesca Milocco - Stratingh Institute for Chemistry, University of Groningen, 9747 AG Groningen, The Netherlands

Folkert de Vries - Stratingh Institute for Chemistry, University of Groningen, 9747 AG Groningen, The Netherlands

Imke M. A. Bartels - Stratingh Institute for Chemistry, University of Groningen, 9747 AG Groningen, The Netherlands

Remco W. A. Havenith - Stratingh Institute for Chemistry and Zernike Institute for Advanced Materials, University of Groningen, 9747 AG Groningen, The Netherlands; Ghent Quantum Chemistry Group, Department of Inorganic and Physical Chemistry, Ghent University, B-9000 Gent, Belgium; ○ orcid.org/0000-0003-0038-6030

Jordi Cirera - Departament de Química Inorgànica $i$ Orgànica and Institut de Recerca de Química Teòrica $i$ Computacional, Universitat de Barcelona, 08028 Barcelona, Spain

Serhiy Demeshko - Institut für Anorganische Chemie, Universität Göttingen, 37077 Göttingen, Germany

Franc Meyer - Institut für Anorganische Chemie, Universität Göttingen, 37077 Göttingen, Germany; 이이.org/00000002-8613-7862

Complete contact information is available at:

https://pubs.acs.org/10.1021/jacs.0c10010

\section{Notes}

The authors declare no competing financial interest.

\section{ACKNOWLEDGMENTS}

Financial support from The Netherlands Organization for Scientific Research (NWO) is gratefully acknowledged (VIDI grant to E.O.). We thank the Center for Information Technology of the University of Groningen for their support and for providing access to the Peregrine high performance computing cluster and Prof. Wesley Browne and Dr. Johannes Klein (University of Groningen) for access to VT-UV/vis spectroscopy. J.C. thanks the Spanish MICINN for a Ramón y Cajal research contract (RYC2018-024692-I) and the Spanish Structures of Excellence María de Maeztu program (MDM2017-0767). This work was sponsored by NWO Exact and Natural Sciences for the use of supercomputer facilities (Contract No. 17197 7095).

\section{REFERENCES}

(1) (a) Schröder, D.; Shaik, S.; Schwarz, H. Two-State Reactivity as a New Concept in Organometallic Chemistry. Acc. Chem. Res. 2000, 33, 139. (b) Shaik, S.; Hirao, H.; Kumar, D. Reactivity of High-Valent Iron-Oxo Species in Enzymes and Synthetic Reagents: A Tale of Many States. Acc. Chem. Res. 2007, 40, 532. (c) Crestoni, M. E.; Fornarini, S.; Lanucara, F.; Warren, J. J.; Mayer, J. M. Probing 'SpinForbidden' Oxygen-Atom Transfer: Gas-Phase Reactions of Chromium-Porphyrin Complexes. J. Am. Chem. Soc. 2010, 132, 4336. (d) Holland, P. L. Distinctive Reaction Pathways at Base Metals in High-Spin Organometallic Catalysts. Acc. Chem. Res. 2015, 48, 1696. (e) Hu, L.; Chen, H. Substrate-Dependent Two-State Reactivity in Iron-Catalyzed Alkene [2+2] Cycloaddition Reactions. J. Am. Chem. Soc. 2017, 139, 15564. (f) Kepp, K. P. Heme: From quantum spin crossover to oxygen manager of life. Coord. Chem. Rev. 2017, 344, 363. (g) Hickey, A. K.; Lutz, S. A.; Chen, C.-H.; Smith, J. M. Twostate reactivity in $\mathrm{C}-\mathrm{H}$ activation by a four-coordinate iron(0) complex. Chem. Commun. 2017, 53, 1245.

(2) Cambi, L.; Szegö, L. Über die magnetische Susceptibilität der komplexen Verbindungen. Ber. Dtsch. Chem. Ges. B 1931, 64, 2591.

(3) (a) Kahn, O.; Kröber, J.; Jay, C. Spin Transition Molecular Materials for displays and data recording. Adv. Mater. 1992, 4, 718. (b) Kahn, O.; Martinez, C. J. Spin-Transition Polymers: From Molecular Materials Toward Memory Devices. Science 1998, 279, 44.

(4) (a) Spin Crossover in Transition Metal Compounds I-III; Gütlich, P., Goodwin, H. A., Eds.; Springer: 2004; Vols. 233-235.

(b) Halcrow, M. A. Spin-Crossover Materials: Properties and Applications; John Wiley \& Sons: Somerset, NJ, 2013.

(5) Halcrow, M. The Effect of Ligand Design on Metal Ion Spin State-Lessons from Spin Crossover Complexes. Crystals 2016, 6, 58.

(6) Gütlich, P.; Gaspar, A. B.; Garcia, Y. Spin state switching in iron coordination compounds. Beilstein J. Org. Chem. 2013, 9, 342.

(7) (a) Halcrow, M. A. Structure:function relationships in molecular spin-crossover complexes. Chem. Soc. Rev. 2011, 40, 4119. (b) Halcrow, M. A. Spin-crossover Compounds with Wide Thermal Hysteresis. Chem. Lett. 2014, 43, 1178.

(8) (a) Hagiwara, H.; Okada, S. A polymorphism-dependent $T_{1 / 2}$ shift of $100 \mathrm{~K}$ in a hysteretic spin-crossover complex related to differences in intermolecular weak $\mathrm{CH} \cdots \mathrm{X}$ hydrogen bonds $(\mathrm{X}=\mathrm{S}$ vs. S and N). Chem. Commun. 2016, 52, 815. (b) Phukkaphan, N.; Cruickshank, D. L.; Murray, K. S.; Phonsri, W.; Harding, P.; Harding, D. J. Hysteretic spin crossover driven by anion conformational change. Chem. Commun. 2017, 53, 9801. (c) Rodríguez-Jiménez, S.; Brooker, S. Solid Versus Solution Spin Crossover and the Importance of the $\mathrm{Fe}-\mathrm{N} \equiv \mathrm{C}(\mathrm{X})$ Angle. Inorg. Chem. 2017, 56, 13697. (d) Vela, S.; Paulsen, H. Cooperativity in Spin Crossover Systems. An Atomistic Perspective on the Devil's Staircase. Inorg. Chem. 2018, 57, 9478. (e) Kitchen, J. A.; White, N. G.; Jameson, G. N.; Tallon, J. L.; Brooker, S. Effect of counteranion X on the spin crossover properties of a family of diiron(II) triazole complexes $\left[\mathrm{Fe}(\mathrm{II})_{2}(\mathrm{PMAT})_{2}\right](\mathrm{X})_{4}$. Inorg. Chem. 2011, 50, 4586. (f) Zhang, W.; Zhao, F.; Liu, T.; Yuan, M.; Wang, Z. M.; Gao, S. Spin crossover in a series of iron(II) complexes of 2-(2-Alkyl-2H-tetrazol-5-yl)-1,10-phenanthroline: effects of alkyl side chain, solvent, and anion. Inorg. Chem. 2007, 46, 2541.

(9) Bowman, A. C.; Milsmann, C.; Bill, E.; Turner, Z. R.; Lobkovsky, E.; DeBeer, S.; Wieghardt, K.; Chirik, P. J. Synthesis and Electronic Structure Determination of N-Alkyl-Substituted Bis(imino)pyridine 
Iron Imides Exhibiting Spin Crossover Behavior. J. Am. Chem. Soc. 2011, 133, 17353.

(10) (a) Scepaniak, J. J.; Harris, T. D.; Vogel, C. S.; Sutter, J.; Meyer, K.; Smith, J. M. Spin Crossover in a Four-Coordinate Iron(II) Complex. J. Am. Chem. Soc. 2011, 133, 3824. (b) Lin, H.-J.; Siretanu, D.; Dickie, D. A.; Subedi, D.; Scepaniak, J. J.; Mitcov, D.; Clérac, R.; Smith, J. M. Steric and Electronic Control of the Spin State in ThreeFold Symmetric, Four-Coordinate Iron(II) Complexes. J. Am. Chem. Soc. 2014, 136, 13326.

(11) Creutz, S. E.; Peters, J. C. Spin-State Tuning at Pseudotetrahedral $\mathrm{d}^{6}$ Ions: Spin Crossover in $\left[\mathrm{BP}_{3}\right] \mathrm{Fe}^{\mathrm{II}}-\mathrm{X}$ Complexes. Inorg. Chem. 2016, 55, 3894.

(12) (a) Jenkins, D. M.; Di Bilio, A. J.; Allen, M. J.; Betley, T. A.; Peters, J. C. Elucidation of a Low Spin Cobalt(II) System in a Distorted Tetrahedral Geometry. J. Am. Chem. Soc. 2002, 124, 15336. (b) Alvarez, S.; Cirera, J. How High the Spin? Allowed and Forbidden Spin States in Transition-Metal Chemistry. Angew. Chem., Int. Ed. 2006, 45, 3012. (c) Tangen, E.; Conradie, J.; Ghosh, A. Bonding in Low-Coordinate Environments: Electronic Structure of Pseudotetrahedral Iron-Imido Complexes. J. Chem. Theory Comput. 2007, 3, 448.

(13) A more general theoretical treatment for "inverted ligand fields" as a consequence of $\sigma$-noninnocence is given in: Hoffmann, R.; Alvarez, S.; Mealli, C.; Falceto, A.; Cahill, T. J.; Zeng, T.; Manca, G. Chem. Rev. 2016, 116, 8173.

(14) Travieso-Puente, R.; Broekman, J. O. P.; Chang, M.-C.; Demeshko, S.; Meyer, F.; Otten, E. Spin-Crossover in a Pseudotetrahedral Bis(formazanate) Iron Complex. J. Am. Chem. Soc. 2016, 138, 5503.

(15) Milocco, F.; Demeshko, S.; Meyer, F.; Otten, E. Ferrate(II) complexes with redox-active formazanate ligands. Dalton Trans. 2018, 47, 8817.

(16) Panda, A.; Stender, M.; Wright, R. J.; Olmstead, M. M.; Klavins, P.; Power, P. P. Synthesis and Characterization of Three-Coordinate and Related $\beta$-Diketiminate Derivatives of Manganese, Iron, and Cobalt. Inorg. Chem. 2002, 41, 3909.

(17) (a) Halder, G. J.; Kepert, C. J.; Moubaraki, B.; Murray, K. S.; Cashion, J. D. Guest-Dependent Spin Crossover in a Nanoporous Molecular Framework Material. Science 2002, 298, 1762. (b) Ohtani, R.; Hayami, S. Guest-Dependent Spin-Transition Behavior of Porous Coordination Polymers. Chem. - Eur. J. 2017, 23, 2236. (c) Wang, Y.T.; Li, S.-T.; Wu, S.-Q.; Cui, A.-L.; Shen, D.-Z.; Kou, H.-Z. Spin Transitions in $\mathrm{Fe}(\mathrm{II})$ Metallogrids Modulated by Substituents, Counteranions, and Solvents. J. Am. Chem. Soc. 2013, 135, 5942. (d) Steinert, M.; Schneider, B.; Dechert, S.; Demeshko, S.; Meyer, F. Spin-State Versatility in a Series of Fe $4[2 \times 2]$ Grid Complexes: Effects of Counteranions, Lattice Solvent, and Intramolecular Cooperativity. Inorg. Chem. 2016, 55, 2363. (e) Nihei, M.; Han, L.; Oshio, H. Magnetic Bistability and Single-Crystal-to-Single-Crystal Transformation Induced by Guest Desorption. J. Am. Chem. Soc. 2007, 129, 5312. (f) Cai, L.-Z.; Jiang, X.-M.; Zhang, Z.-J.; Guo, P.-Y.; Jin, A.-P.; Wang, M.-S.; Guo, G.-C. Reversible Single-Crystal-toSingle-Crystal Transformation and Magnetic Change of Nonporous Copper(II) Complexes by the Chemisorption/Desorption of $\mathrm{HCl}$ and $\mathrm{H}_{2} \mathrm{O}$. Inorg. Chem. 2017, 56, 1036. (g) Fumanal, M.; JiménezGrávalos, F.; Ribas-Arino, J.; Vela, S. Lattice-Solvent Effects in the Spin-Crossover of an Fe(II)-Based Material. The Key Role of Intermolecular Interactions between Solvent Molecules. Inorg. Chem. 2017, 56, 4474.

(18) Lakhloufi, S.; Lemée-Cailleau, M. H.; Chastanet, G.; Rosa, P.; Daro, N.; Guionneau, P. Structural movies of the gradual spincrossover in a molecular complex at various physical scales. Phys. Chem. Chem. Phys. 2016, 18, 28307.

(19) Törnroos, K. W.; Hostettler, M.; Chernyshov, D.; Vangdal, B.; Bürgi, H.-B. Interplay of Spin Conversion and Structural Phase Transformations: Re-Entrant Phase Transitions in the 2-Propanol Solvate of Tris(2-picolylamine)iron(II) Dichloride. Chem. - Eur. J. 2006, 12, 6207.
(20) Jacobi, B. G.; Laitar, D. S.; Pu, L.; Wargocki, M. F.; DiPasquale, A. G.; Fortner, K. C.; Schuck, S. M.; Brown, S. N. Stoichiometric and Catalytic Oxygen Activation by Trimesityliridium(III). Inorg. Chem. 2002, 41, 4815.

(21) Römelt, M.; Ye, S.; Neese, F. Calibration of Modern Density Functional Theory Methods for the Prediction of 57Fe Mössbauer Isomer Shifts: Meta-GGA and Double-Hybrid Functionals. Inorg. Chem. 2009, 48, 784.

(22) Kläui, W.; Eberspach, W.; Gütlich, P. Spin-crossover cobalt(III) complexes: steric and electronic control of spin state. Inorg. Chem. 1987, 26, 3977.

(23) (a) Toftlund, H. Spin Equilibrium in Solutions. Monatsh. Chem. 2001, 132, 1269. (b) Hassan, N.; Koudriavtsev, A. B.; Linert, W. Isoequilibrium relationships and cooperative effects in spin-state transitions in solution. Pure Appl. Chem. 2008, 80, 1281. (c) Shores, M. P.; Klug, C. M.; Fiedler, S. R. In Spin-Crossover Materials: Properties and Applications; Halcrow, M. A., Ed.; John Wiley \& Sons: 2013.

(24) Although compound 3 also differs in $\mathrm{R}^{\mathrm{C}}$ ( $\mathrm{H}$ instead of $\mathrm{Me}$ ), this has a marginal effect on spin-crossover thermodynamics as indicated by the small difference between $\mathbf{1}$ and $\mathbf{6}$.

(25) (a) Kepp, K. P. Theoretical Study of Spin Crossover in 30 Iron Complexes. Inorg. Chem. 2016, 55, 2717. (b) Kepp, K. P. In Transition Metals in Coordination Environments: Computational Chemistry and Catalysis Viewpoints; Broclawik, E., Borowski, T., Radoń, M., Eds.; Springer International Publishing: Cham, 2019; p 1.

(26) Park, J. G.; Jeon, I.-R.; Harris, T. D. Electronic Effects of Ligand Substitution on Spin Crossover in a Series of DiiminoquinonoidBridged $\mathrm{Fe}(\mathrm{II})_{2}$ Complexes. Inorg. Chem. 2015, 54, 359.

(27) (a) Nakano, K.; Suemura, N.; Yoneda, K.; Kawata, S.; Kaizaki, S. Substituent effect of the coordinated pyridine in a series of pyrazolato bridged dinuclear diiron(II) complexes on the spincrossover behavior. Dalton Trans 2005, 740. (b) Prat, I.; Company, A.; Corona, T.; Parella, T.; Ribas, X.; Costas, M. Assessing the Impact of Electronic and Steric Tuning of the Ligand in the Spin State and Catalytic Oxidation Ability of the FeII(Pytacn) Family of Complexes. Inorg. Chem. 2013, 52, 9229.

(28) Kershaw Cook, L. J.; Kulmaczewski, R.; Mohammed, R.; Dudley, S.; Barrett, S. A.; Little, M. A.; Deeth, R. J.; Halcrow, M. A. A Unified Treatment of the Relationship Between Ligand Substituents and Spin State in a Family of Iron(II) Complexes. Angew. Chem., Int. Ed. 2016, 55, 4327.

(29) Frisch, M. J.; Trucks, G. W.; Schlegel, H. B.; Scuseria, G. E.; Robb, M. A.; Cheeseman, J. R.; Scalmani, G.; Barone, V.; Mennucci, B.; Petersson, G. A.; Nakatsuji, H.; Caricato, M.; Li, X.; Hratchian, H. P.; Izmaylov, A. F.; Bloino, J.; Zheng, G.; Sonnenberg, J. L.; Hada, M.; Ehara, M.; Toyota, K.; Fukuda, R.; Hasegawa, J.; Ishida, M.; Nakajima, T.; Honda, Y.; Kitao, O.; Nakai, H.; Vreven, T.; Montgomery, Jr., J. A.; Peralta, J. E.; Ogliaro, F.; Bearpark, M. J.; Heyd, J.; Brothers, E. N.; Kudin, K. N.; Staroverov, V. N.; Kobayashi, R.; Normand, J.; Raghavachari, K.; Rendell, A. P.; Burant, J. C.; Iyengar, S. S.; Tomasi, J.; Cossi, M.; Rega, N.; Millam, N. J.; Klene, M.; Knox, J. E.; Cross, J. B.; Bakken, V.; Adamo, C.; Jaramillo, J.; Gomperts, R.; Stratmann, R. E.; Yazyev, O.; Austin, A. J.; Cammi, R.; Pomelli, C.; Ochterski, J. W.; Martin, R. L.; Morokuma, K.; Zakrzewski, V. G.; Voth, G. A.; Salvador, P.; Dannenberg, J. J.; Dapprich, S.; Daniels, A. D.; Farkas, Ö.; Foresman, J. B.; Ortiz, J. V.; Cioslowski, J.; Fox, D. J. Gaussian 09, Rev. D.01; Gaussian, Inc.: 2009.

(30) (a) Hoe, W. M.; Cohen, A. J.; Handy, N. C. Assessment of a new local exchange functional OPTX. Chem. Phys. Lett. 2001, 341, 319. (b) Handy, N. C.; Cohen, A. J. Left-right correlation energy. Mol. Phys. 2001, 99, 403. (c) Perdew, J. P.; Burke, K.; Ernzerhof, M. Generalized gradient approximation made simple. Phys. Rev. Lett. 1996, 77, 3865. (d) Perdew, J. P.; Burke, K.; Ernzerhof, M. Generalized Gradient Approximation Made Simple [Phys. Rev. Lett. 77, 3865 (1996)] Phys. Rev. Lett. 1997, 78, $1396 .$.

(31) Schafer, A.; Huber, C.; Ahlrichs, R. Fully Optimized Contracted Gaussian-Basis Sets of Triple Zeta Valence Quality for Atoms Li to Kr. J. Chem. Phys. 1994, 100, 5829. 
(32) Cirera, J.; Ruiz, E. Theoretical Modeling of the Ligand-Tuning Effect over the Transition Temperature in Four-Coordinated $\mathrm{Fe}^{\mathrm{II}}$ Molecules. Inorg. Chem. 2016, 55, 1657.

(33) (a) Knizia, G. Intrinsic Atomic Orbitals: An Unbiased Bridge between Quantum Theory and Chemical Concepts. J. Chem. Theory Comput. 2013, 9, 4834. (b) Knizia, G.; Klein, J. E. M. N. Electron Flow in Reaction Mechanisms-Revealed from First Principles. Angew. Chem., Int. Ed. 2015, 54, 5518.

(34) APEX3, SAINT and SADABS; Bruker AXS Inc.: Madison, WI, 2016

(35) Sheldrick, G. A short history of SHELX. Acta Crystallogr., Sect. A: Found. Crystallogr. 2008, 64, 112.

(36) Sheldrick, G. Crystal structure refinement with SHELXL. Acta Crystallogr., Sect. C: Struct. Chem. 2015, 71, 3.

(37) Spek, A. PLATON SQUEEZE: a tool for the calculation of the disordered solvent contribution to the calculated structure factors. Acta Crystallogr., Sect. C: Struct. Chem. 2015, 71, 9.

(38) Sheldrick, G. M. CELL_NOW; Universität Göttingen: Germany, 2008.

(39) Sheldrick, G. M. TWINABS; Universität Göttingen: Germany, 2012. 